\title{
Gibberellin JRA-003: A Selective Inhibitor of Nuclear Translocation of IKK $\alpha$
}

James R. Annand, ${ }^{1,2}$ Andrew R. Henderson, ${ }^{2}$ Kyle S. Cole, ${ }^{3}$ Aaron J. Maurais, ${ }^{3}$ Jorge Becerra, ${ }^{2}$ Yejun Liu, ${ }^{2}$ Eranthie Weerapana,${ }^{3}$ Angela N. Koehler, ${ }^{4}$ Anna K. Mapp, ${ }^{1,2}$ and Corinna S.

Schindler. ${ }^{*}, 1,2$

${ }^{1}$ Department of Chemistry, Willard-Henry-Dow Laboratory, University of Michigan, 930 N University Ave., Ann Arbor, MI 48109

${ }^{2}$ Program in Chemical Biology, University of Michigan, 210 Washtenaw Ave, Ann Arbor, MI 48109

${ }^{3}$ Department of Chemistry, Merkert Center, Boston College, 2609 Beacon St., Chestnut Hill, MA 02467

${ }^{4}$ David H. Koch Institute for Integrative Cancer Research, Massachusetts Institute of Technology, 500 Main St., Cambridge, MA 02139

\section{Supporting Information}

1. Supplementary Figures

S2

2. Materials and Methods

S7

3. Synthetic Procedures

S11

4. NMR Spectra

S23

5. References

S39 


\section{Supplementary Information Section 1: Supplementary Figures}

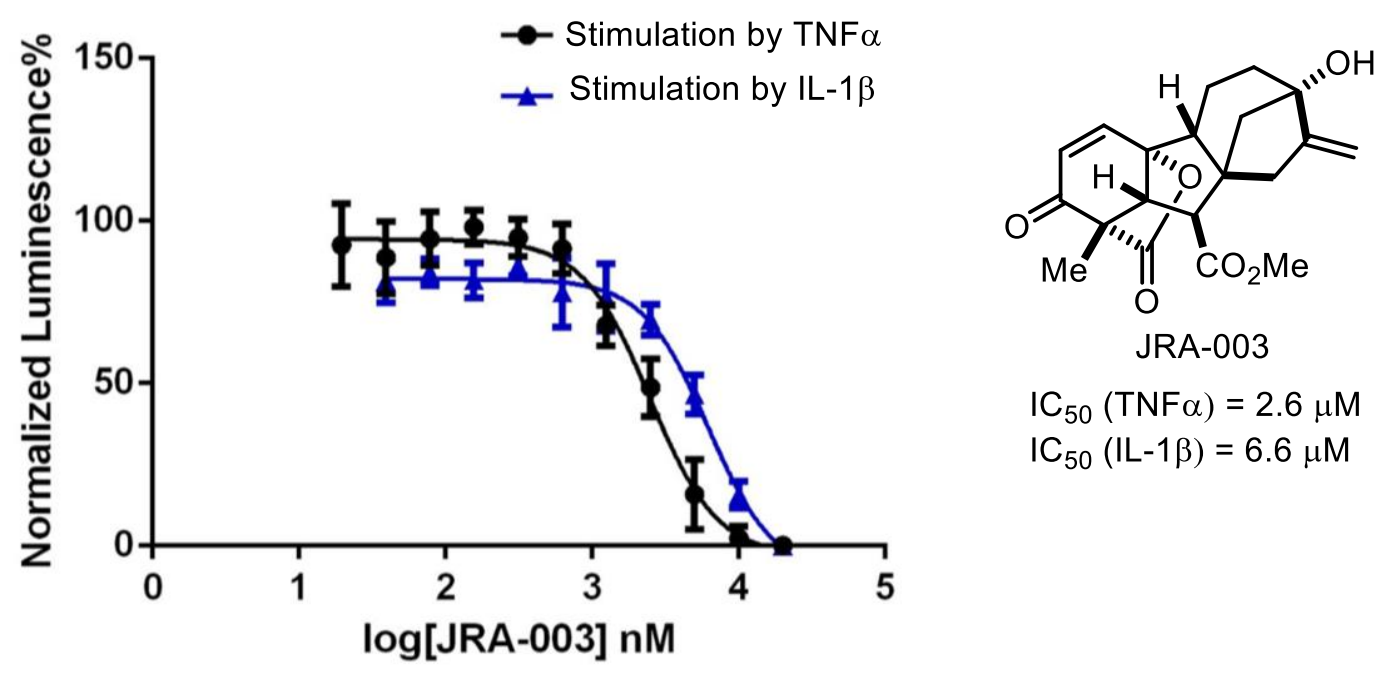

Supplemental Figure S1. Activity curves of JRA-003 in a commercially available HEK 293T cell line stably transfected with a Luc2P reporter gene controlled by six sequential NF- $\kappa B$ response elements. JRA-003 efficiently inhibits NF- $\mathrm{B}$ signaling in cells in which the pathway has been stimulated by either $\mathrm{IL}-1 \beta$ or $\mathrm{TNF} \alpha . \mathrm{n}=3$ biological replicates. 


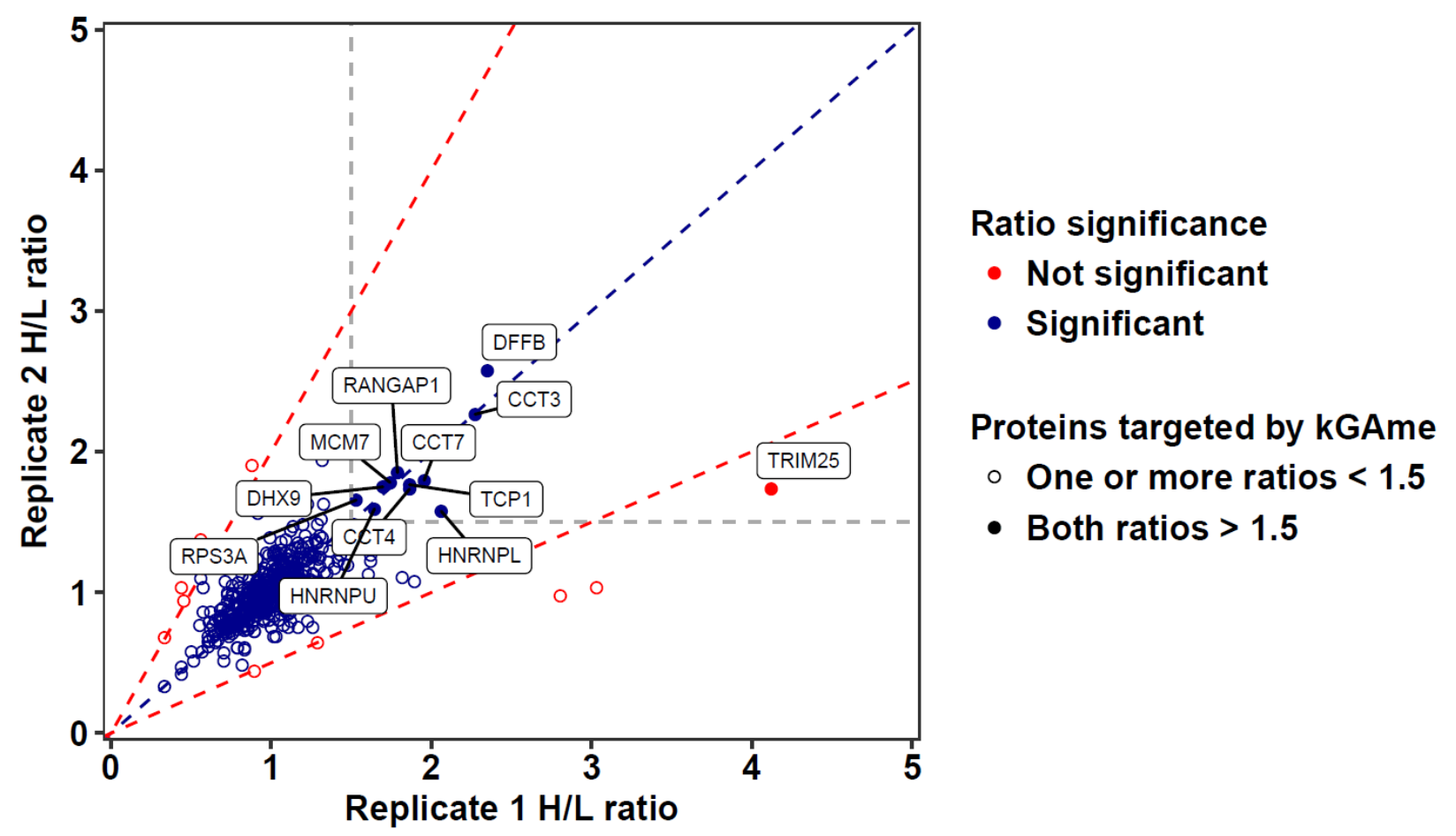

Supplemental Figure S2. A proteome wide analysis of SILAC mass spec proteomics in cells pretreated with DMSO (heavy cells) or JRA-003 (light cells) and subsequently pulled down with JRA-031. Targets were found to be significant if spectral counts were found to be $>50$ and the ratio of heavy spectral counts/light spectral counts were $>1.5$ in both biological replicates. 


\begin{tabular}{|c|c|c|c|c|c|c|c|c|c|}
\hline & $\alpha-\operatorname{Re} \mid A$ & DAPI & merge & $\alpha-\operatorname{RelB}$ & DAPI & merge & $\alpha-c-R e l$ & DAPI & merge \\
\hline $\begin{array}{l}\text { DMSO } \\
- \text { IL-1 }\end{array}$ & & & & & 18 & & & & \\
\hline $\begin{array}{l}\text { DMSO } \\
+ \text { IL-1 }\end{array}$ & 8 & & & & & & & & \\
\hline $\begin{array}{c}\text { JRA-003 (1 } \\
(10 \mu \mathrm{M}) \\
+\mathrm{IL}-1 \beta\end{array}$ & & & & & & & & & \\
\hline
\end{tabular}

Supplemental Figure S3. Immunohistochemical staining and confocal microscopy of HeLa cells. Cells were pretreated with DMSO or JRA-003 before stimulation by IL-1 $\beta$ or treatment with vehicle. AF488 tagged antibodies were used to image NF- $\mathrm{kB}$ pathway members and DAPI was employed as a nuclear stain. 
A. Med25-AcID incubated with 1 eq JRA-002

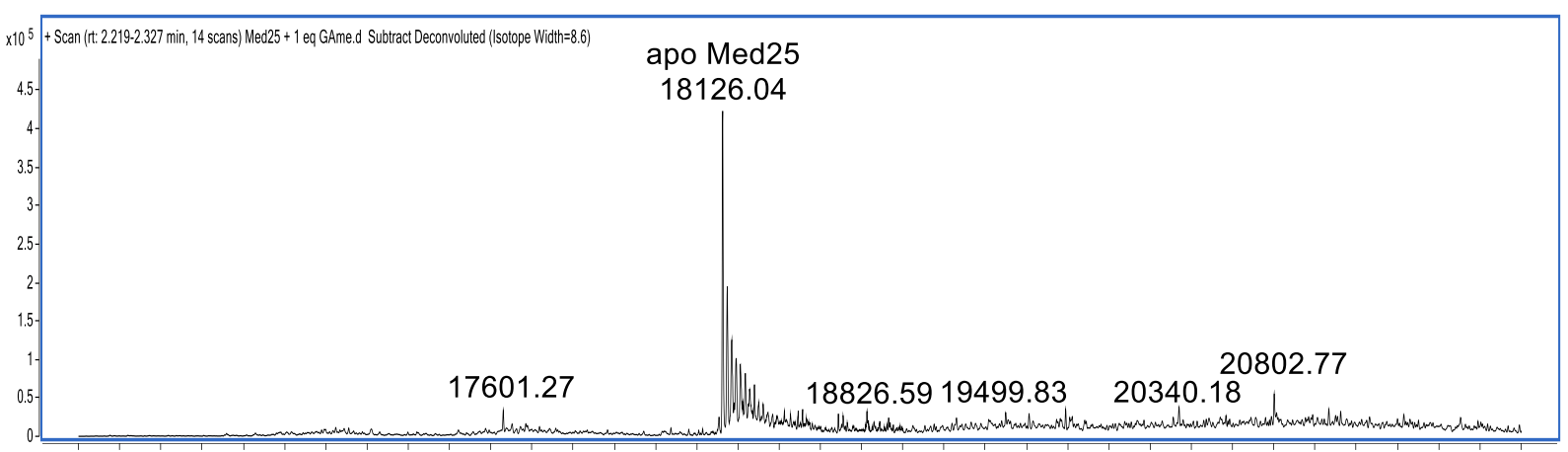

150001520015400156001580016000162001640016600168001700017200174001760017800180001820018400186001880019000192001940019600198002000020200204002060020800210002120021400216002180022000

B. Med25 incubated with 1 eq JRA-003

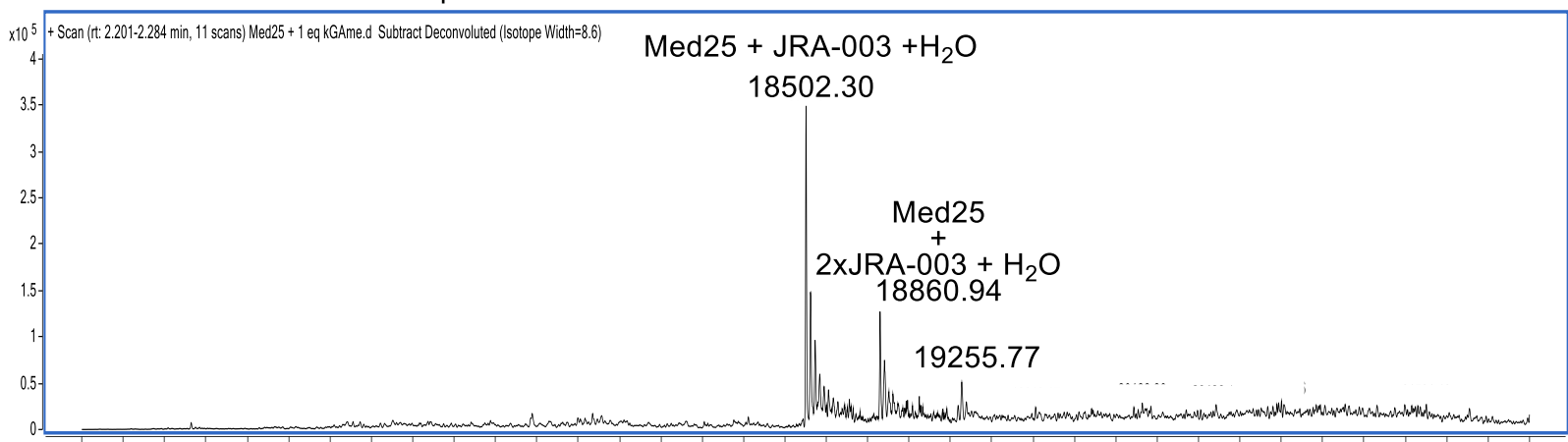

150001520015400156001580016000162001640016600168001700017200174001760017800180001820018400186001880019000192001940019600198002000020200204002060020800210002120021400216002180022000 Counts vs. Deconvoluted Mass (amu)

Supplemental Figure S4. Med25 Activator Interaction Domain (AcID) was incubated $12 \mathrm{~h}$ with 1 molar equivalent of synthetic gibberellins. A. Incubation with JRA-002 returns apo Med25-AcID (MW $=18126)$ as the major peak. B. Incubation with JRA-003 (MW = 358.4) returns the mono-labeled Med25-AcID as the major product with some dilabled Med25-AcID and no unlabeled Med25-AcID. 
Supplementary Table S1. High throughput evaluation of synthetic gibberellin analogs.

\begin{tabular}{|c|c|c|c|c|c|c|c|c|c|c|}
\hline \multicolumn{11}{|c|}{ Cell Titre Glo $^{\otimes} \mathrm{EC}_{50}(\mathrm{nM})$} \\
\hline compound & $\begin{array}{l}\text { P3HR-1 } \\
\text { Burkitt's } \\
\text { lymphoma }\end{array}$ & $\begin{array}{c}\text { SNU-16 } \\
\text { gastric } \\
\text { carcinoma }\end{array}$ & $\begin{array}{c}\text { HT-29 } \\
\text { colorectal } \\
\text { adenocarcinoma }\end{array}$ & $\begin{array}{l}\text { COLO 320DM } \\
\text { colorectal } \\
\text { adenocarcinoma }\end{array}$ & $\begin{array}{c}\text { SNU-398 } \\
\text { hepatocellular } \\
\text { carcinoma }\end{array}$ & $\begin{array}{l}\text { MSTO-211H } \\
\text { mesothelioma }\end{array}$ & $\begin{array}{c}\text { Hs 888.T } \\
\text { osteosarcoma }\end{array}$ & $\begin{array}{c}\text { SK-N-MC } \\
\text { neuroepithelioma }\end{array}$ & $\begin{array}{c}\text { HL-60 } \\
\text { leukemia }\end{array}$ & $\begin{array}{c}\text { U-87 MG } \\
\text { glioblastoma }\end{array}$ \\
\hline JRA-001 & N.S. & N.S. & N.S. & N.S. & N.S. & N.S. & N.S. & N.S. & N.S. & N.S. \\
\hline JRA-002 & N.S. & N.S. & N.S. & N.S. & N.S. & N.S. & N.S. & N.S. & N.S. & N.S. \\
\hline JRA-003 & 560 & 2500 & N.S. & 1300 & 10,000 & N.S. & 740 & $<40$ & $<40$ & 64 \\
\hline JRA-004 & N.S. & N.S. & N.S. & N.S. & N.S. & N.S. & N.S. & N.S. & N.S. & N.S. \\
\hline JRA-005 & N.S. & N.S. & N.S. & N.S. & N.S. & N.S. & N.S. & N.S. & N.S. & N.S. \\
\hline JRA-006 & N.S. & N.S. & N.S. & N.S. & N.S. & N.S. & N.S. & N.S. & N.S. & N.S. \\
\hline JRA-007 & N.S. & N.S. & N.S. & N.S. & N.S. & N.S. & N.S. & N.S. & N.S. & N.S. \\
\hline JRA-008 & N.S. & N.S. & N.S. & N.S. & N.S. & N.S. & N.S. & N.S. & N.S. & N.S. \\
\hline JRA-009 & N.S. & N.S. & N.S. & N.S. & N.S. & N.S. & N.S. & N.S. & N.S. & N.S. \\
\hline JRA-010 & N.S. & N.S. & N.S. & N.S. & N.S. & N.S. & N.S. & N.S. & N.S. & N.S. \\
\hline JRA-011 & N.S. & N.S. & N.S. & N.S. & N.S. & N.S. & N.S. & N.S. & N.S. & N.S. \\
\hline JRA-012 & N.S. & N.S. & N.S. & N.S. & N.S. & N.S. & N.S. & N.S. & N.S. & N.S. \\
\hline JRA-013 & N.S. & N.S. & N.S. & N.S. & N.S. & N.S. & N.S. & N.S. & N.S. & N.S. \\
\hline JRA-014 & N.S. & N.S. & N.S. & N.S. & N.S. & N.S. & N.S. & N.S. & N.S. & N.S. \\
\hline JRA-015 & N.S. & N.S. & N.S. & N.S. & N.S. & N.S. & N.S. & N.S. & N.S. & N.S. \\
\hline JRA-017 & N.S. & N.S. & N.S. & N.S. & N.S. & N.S. & N.S. & N.S. & N.S. & N.S. \\
\hline JRA-018 & N.S. & N.S. & N.S. & N.S. & N.S. & N.S. & N.S. & N.S. & N.S. & N.S. \\
\hline JRA-019 & 1200 & 3100 & N.S. & 4100 & 7300 & N.S. & 10,000 & 95 & $<40$ & 1100 \\
\hline JRA-021 & N.S. & N.S. & N.S. & N.S. & N.S. & N.S. & N.S. & N.S. & N.S. & N.S. \\
\hline JRA-022 & 1600 & 1700 & N.S. & 5100 & 3700 & N.S. & 8600 & 69 & $<40$ & 2200 \\
\hline JRA-023 & N.S. & N.S. & N.S. & N.S. & N.S. & N.S. & N.S. & N.S. & N.S. & N.S. \\
\hline JRA-026 & 1700 & N.S. & N.S. & 8300 & N.S. & N.S. & 7500 & 2400 & 700 & 260 \\
\hline JRA-027 & N.S. & N.S. & N.S. & N.S. & N.S. & N.S. & N.S. & N.S. & N.S. & N.S. \\
\hline JRA-028 & N.S. & N.S. & N.S. & N.S. & N.S. & N.S. & N.S. & N.S. & N.S. & N.S. \\
\hline JRA-029 & 6300 & 10,000 & N.S. & N.S. & N.S. & N.S. & N.S. & 3000 & 3100 & 2400 \\
\hline
\end{tabular}

Cell Titre Glo® viability assay was conducted by HTE. Data reported as average of $n=2$. N.S. $=$ Not Significant $\left(E_{50}>10,000 n M\right)$. 


\section{Supplementary Information Section 2: Materials and Methods}

Luciferase Reporter Gene Assay Hek 293 cells stably transfected with a firefly luciferase gene controlled by six sequential NF- $\kappa$ B response elements (BPS Biosciences \#60650) were grown according to the manufacturers specifications to $80 \%$ confluence and were split into white opaque 96 -well plates at a density of 30,000 cells/well in $90 \mathrm{uL}$ DMEM supplemented with $10 \% \mathrm{FBS}$ where they were incubated at $37^{\circ} \mathrm{C}$ with $5 \% \mathrm{CO}_{2}$ overnight. The cells were dosed with compound (to a final \%DMSO of $0.1 \%$ ), or vehicle for $1 \mathrm{~h}$ at $37{ }^{\circ} \mathrm{C}$ with $5 \% \mathrm{CO}_{2}$. Then the NF- $\kappa B$ pathway was stimulated with either $\mathrm{TNF} \alpha$ (to a final concentration of $20 \mathrm{ng} / \mathrm{mL}$ ), IL-1 $\beta$ (to a final concentration of $2 \mathrm{ng} / \mathrm{mL}$ ), or vehicle as an unstimulated control. The cells were incubated at $37{ }^{\circ} \mathrm{C}$ with $5 \% \mathrm{CO}_{2}$ for $3 \mathrm{~h}$ before being analyzed using the ONE-Step ${ }^{\mathrm{TM}}$ Luciferase Assay System (BPS Biosceinces \#60690) according to the manufacturers specifications. $\mathrm{EC}_{50} \mathrm{~s}$ were determined using 10 point dose response curves. Response curve analytics were performed using GraphPad software.

Pulldowns with Western blotting HeLa cells were grown in DMEM supplemented with 10\% FBS at 37 ${ }^{\circ} \mathrm{C}$ with $5 \% \mathrm{CO}_{2}$ to $80 \%$ confluence. The cells were plated at $2 \times 10^{6}$ cells/well in a 6 well plate and allowed to adhere for $16 \mathrm{~h}$. The media was removed, and the cells were stimulated with either Opti-MEM containing $2 \mathrm{ng} / \mathrm{mL} \mathrm{IL}-1 \beta$ or Opti-MEM alone for $3 \mathrm{~h}$ at $37{ }^{\circ} \mathrm{C}$ with $5 \% \mathrm{CO}_{2}$. Following stimulation, the media was removed, and the cells were lysed with $1 \mathrm{~mL} \mathrm{NP}-40$ lysis buffer $(150 \mathrm{mM} \mathrm{NaCl}, 1 \% \mathrm{NP}-40,50 \mathrm{mM}$ Tris pH 8.0, HALT protease inhibitor) at $4{ }^{\circ} \mathrm{C}$ on an orbital shaker for $15 \mathrm{~min}$. Cell lysate was spun down at $14,000 \mathrm{rpm}$ at $4{ }^{\circ} \mathrm{C}$ for $20 \mathrm{~min} .100 \mu \mathrm{L}$ of lysate was treated with compound as indicated and mixed via end over end tumbling for $2 \mathrm{~h}$ at $23{ }^{\circ} \mathrm{C}$. Biotin-Azide (Click Chemistry Tools) was added along with a copper catalyst solution (prepared according to Jena Biosciences Click Chemistry Capture Kit CLK-1065). $50 \mu \mathrm{L}$ of washed ( $6 x$ with $1 \mathrm{~mL}$ of $10 \mathrm{mM} \mathrm{Na}_{3} \mathrm{PO}_{4}, 150 \mathrm{mM} \mathrm{NaCl}, 0.1 \% \mathrm{NP}-40,10 \%$ glycerol, pH 7.2) magnetic SpeedBead beads were added and mixed end over end for $16 \mathrm{~h}$ at $4{ }^{\circ} \mathrm{C}$. The Neutravadin beads were pelleted using a permanent magnet, the lysate was removed, and the pellet was washed $(6 \mathrm{x}$ with $1 \mathrm{~mL}$ of $10 \mathrm{mM}$ $\mathrm{Na}_{3} \mathrm{PO}_{4}, 150 \mathrm{mM} \mathrm{NaCl}, 0.1 \% \mathrm{NP}-40,10 \%$ glycerol, $\mathrm{pH}$ 7.2). Next $18.75 \mu \mathrm{L}$ of NuPAGE LDS sample buffer (Invitrogen) and $6.25 \mu \mathrm{L}$ of $1 \mathrm{mM}$ DTT was added to the beads and they were boiled at $95{ }^{\circ} \mathrm{C}$, vortexing periodically, for $10 \mathrm{~min}$. The proteins were quantified with a Bradford assay and an equal amount of protein was loaded into a 10\% Bis-Tris SDS-PAGE gel. Western blotting was performed using the indicated NF- $\kappa \mathrm{B}$ antibodies (Abcam; 1:500 dilution).

Immunohistochemical Staining and Confocal Imaging HeLa cells were grown in DMEM supplemented with $10 \% \mathrm{FBS}$ at $37{ }^{\circ} \mathrm{C}$ with $5 \% \mathrm{CO}_{2}$ to $80 \%$ confluence. They were plated at $1.25 \times 10^{6} \mathrm{cells} / \mathrm{mL}$ in DMEM supplemented with $10 \%$ FBS on tissue culture treated microscope slides. The cells were treated with compound as indicated to $0.1 \%$ DMSO and incubated for $1 \mathrm{~h}$ at $37{ }^{\circ} \mathrm{C}$ with $5 \% \mathrm{CO}_{2}$. The cells were then stimulated or treated with vehicle as indicated, with $2 \mathrm{ng} / \mathrm{mL} \mathrm{IL}-1 \beta$ for $1 \mathrm{~h}$ at $37{ }^{\circ} \mathrm{C}$ with $5 \% \mathrm{CO}_{2}$. The media was aspirated, and the cells were fixed with $37^{\circ} \mathrm{C}$ fixing solution (4\% methanol-formaldehyde, PBS, $\mathrm{pH}$ 7.4) for $10 \mathrm{~min}$ at $23^{\circ} \mathrm{C}$. The fixing solution was removed, and the cells were washed with PBS pH 7.4. The cells were permeabilized with $0.2 \%$ Triton X-100 in PBS, pH 7.4 for 10 min. The permeabilization buffer was removed and the cells were washed twice with PBS, pH 7.4. The cells were blocked for $30 \mathrm{~min}$ with $10 \%$ normal goat serum in PBS, $\mathrm{pH}$ 7.4. The cells were washed once with PBS, $\mathrm{pH}$ 7.4. The cells were incubated for $1 \mathrm{~h}$ with primary antibodies (Abcam, 1:100 dilution) in 10\% normal goat serum in PBS, $\mathrm{pH}$ 7.4. The cells were washed twice with $0.1 \%$ Tween 20 in PBS, pH, 7.4. The cells were incubated overnight at $4{ }^{\circ} \mathrm{C}$ with $1 \mu \mathrm{g} / \mathrm{mL}$ DAPI nuclear stain, secondary AlexaFluor 488 antibodies (Invitrogen, 1:1000 dilution) in $1.5 \%$ normal goat serum in PBS, pH 7.4. The cells were washed twice with $0.1 \%$ Tween 20 in PBS, pH 7.4 and the cells were sealed on the microscope slide in PBS, pH 7.4. The images were acquired on a Nikon A1 High Sensitivity Confocal Microscope. 
Cell Fractioning HeLa cells were grown in DMEM supplemented with $10 \% \mathrm{FBS}$ at $37{ }^{\circ} \mathrm{C}$ with $5 \% \mathrm{CO}_{2}$ to $80 \%$ confluence. $5 \times 10^{7}$ cells were plated into $10 \mathrm{cM}$ dishes and allowed to adhere at $37{ }^{\circ} \mathrm{C}$ with $5 \% \mathrm{CO}_{2}$ for $16 \mathrm{~h}$. The media was removed and cells were treated as indicated with compounds or DMSO in OptiMEM to $0.1 \%$ DMSO for $1 \mathrm{~h}$ at $37{ }^{\circ} \mathrm{C}$ with $5 \% \mathrm{CO}_{2}$. The cells were stimulated as indicated with IL- $1 \beta$ to a final concentration of $2 \mathrm{ng} / \mathrm{mL}$ for $3 \mathrm{~h}$ at $37{ }^{\circ} \mathrm{C}$ with $5 \% \mathrm{CO}_{2}$. The media was removed and the cells were scraped at $4{ }^{\circ} \mathrm{C}$ with cold PBS and then pelleted at $2500 \mathrm{rpm}$ for $5 \mathrm{~min}$. The pellet was washed with $10 \mathrm{mM}$ HEPES, $1.5 \mathrm{mM} \mathrm{MgCl} 2,10 \mathrm{mM} \mathrm{KCl}, 0.5 \mathrm{mM}$ PMSF, $0.5 \mathrm{mM}$ DTT. The cells were resuspended to a concentration of $1 \times 10^{6}$ cells $/ 15 \mu \mathrm{L}$ in $10 \mathrm{mM}$ HEPES, $1.5 \mathrm{mM} \mathrm{MgCl}_{2}, 10 \mathrm{mM} \mathrm{KCl}, 0.5 \mathrm{mM}$ PMSF, 0.5 $\mathrm{mM}$ DTT, $0.1 \% \mathrm{NP}-40$ and incubated for $5 \mathrm{~min}$ at $4{ }^{\circ} \mathrm{C}$ with shaking. The nuclei were pelleted by centrifugation at $13,000 \mathrm{rpm}$ at $4{ }^{\circ} \mathrm{C}$ for $15 \mathrm{~min}$. The supernatant was carefully removed as the cytosolic fraction. The nuclear fraction was resuspended in $10 \mu \mathrm{M} / 1 \times 10^{6}$ cells used of $20 \mathrm{mM}$ HEPES, $0.42 \mathrm{mM}$ $\mathrm{NaCl}, 1.5 \mathrm{mM}$ EDTA, 25\% glycerol, $0.5 \mathrm{mM}$ DTT, $0.5 \mathrm{mM}$ PMSF and the fraction was incubated at $4{ }^{\circ} \mathrm{C}$ for 15 min with occasional vortexing. The nuclear fraction was separated from insoluble materials by centrifugation at $13,000 \mathrm{rpm}$ for $15 \mathrm{~min}$ at $4{ }^{\circ} \mathrm{C}$. The supernatant was carefully removed as the nuclear fraction and diluted with $60 \mu \mathrm{L} / 1 \times 10^{6}$ cells used of $20 \mathrm{mM}$ HEPES, $50 \mathrm{mM} \mathrm{KCl,} 0.2 \mathrm{mM}$ EDTA, 20\% glycerol, 0.5 mM DTT, 0.5 mM PMSF. Cytosolic and nuclear fractions were quantified using a Pierce BCA assay and equal protein concentrations were loaded onto a 10\% Bis-Tris SDS-PAGE gel. Western blotting was conducted with the indicated antibodies (Abcam, 1:500 dilution).

High Throughput Cell Titre Glo® Viability Assay Cells were maintained according to manufacturer's recommendation and split at $80 \%$ confluence into duplicate 384-well tissue culture treated plates at 2000 cells/well. A 10-point dilution curve was pinned into the cells twice providing a 1:500-fold dilution. A dilution curve of MG-132, a proteasome inhibitor, was included as a positive control. A full column was reserved for DMSO as a negative control. The edge-wells were treated with DMSO and excluded from analysis. The cells were incubated at $37{ }^{\circ} \mathrm{C}$ with $5 \% \mathrm{CO}_{2}$ for $24 \mathrm{~h}$ prior to analysis via a Cell Titre Glo® Luminescent Cell Viability Assay (Promega) which was run according to the manufacturer's specifications. The data was normalized to the negative control on the plate. Plates with more than $10 \%$ variance in the negative control were re-assayed prior to analysis. $\mathrm{EC}_{50}$ s were determined using GraphPad software.

Determination of JRA-003 Selectivity by Quantitative Mass SpectrometryHEK293T cells were grown in DMEM minus L-lysine and L-arginine (Thermo Scientific), supplemented in 10\% dialyzed FBS (Atlanta Biologicals) and either $84 \mu \mathrm{g} / \mathrm{mL}$ and $146 \mu \mathrm{g} / \mathrm{mL}$ of $\left[{ }^{13} \mathrm{C} /{ }^{15} \mathrm{~N}\right]$-L-arginine (R10) and $\left[{ }^{13} \mathrm{C} /{ }^{15} \mathrm{~N}\right]-\mathrm{L}-\mathrm{lysine}(\mathrm{K} 8)$ or L-arginine (R0) and L-lysine (K0) at $37^{\circ} \mathrm{C}$ and $5 \% \mathrm{CO}_{2}$ for a minimum of 6 passages.

Pulldown experiments were performed with HEK293T cells at $80 \%$ confluency. Cells were pretreated for 1 hour with either DMSO (heavy cells), or $1 \mu \mathrm{M}$ JRA-003 (1) (light cells), followed by labeling with 10 $\mu$ M JRA-031 (4) for 1 hour, and stimulation with $2 \mathrm{ng} / \mathrm{uL}$ IL-1B for 1 hour. Cells were then harvested and lysed by sonication. Protein concentrations were normalized to $2 \mathrm{mg} / \mathrm{mL}$ and $1 \mathrm{mg}$ each of heavy and light labeled lysates were combined. Biotin-azide (Click Chemistry Tools) was appended to alkyne labeled proteins with copper catalyzed click chemistry (CuAAC); $10 \mathrm{mM}$ biotin-azide, $1 \mathrm{mM}$ TCEP, $100 \mu \mathrm{M}(50 \mathrm{x}$ stock in water) TBTA ligand (17x stock in DMSO:t-butanol 1:4), and $1 \mathrm{mM}$ copper(II) sulfate (50x in water). The reaction was allowed to proceed for 1 hour at $25^{\circ} \mathrm{C}$. Samples were centrifuged at $16,000 \mathrm{xg}$ to pellet precipitated protein and pellets were washed $2 \mathrm{x}$ with ice-cold $\mathrm{MeOH}$. Pellets were solubilized in $1.2 \%$ SDS in PBS by sonication and heating $\left(5 \mathrm{~min}, 80^{\circ} \mathrm{C}\right)$. Once dissolved, samples were combined with PBS ( $0.2 \%$ final SDS concentration) and a streptavidin agarose slurry $(170 \mu \mathrm{L})$, and incubated overnight at $4^{\circ} \mathrm{C}$, then for 3 hours at $25^{\circ} \mathrm{C}$. The beads were washed $1 \mathrm{x}$ with $0.2 \%$ SDS in PBS, $3 \mathrm{x}$ with PBS, and $3 \mathrm{x}$ 
with water. Beads were pelleted between washes by centrifugation (1,400 xg for $3 \mathrm{~min})$. The beads were suspended in $500 \mu \mathrm{L}$ of $6 \mathrm{M}$ urea in PBS and $10 \mathrm{mM}$ (from 20x stock in water) and heated at $65^{\circ} \mathrm{C}$ for 20 min. $20 \mathrm{mM}$ iodoacetamide (from 20x stock in water) was added and the samples were incubated at $37^{\circ} \mathrm{C}$ for $30 \mathrm{~min}$. The beads were pelleted by centrifugation (1,400 xg for $3 \mathrm{~min}$ ), resuspended in a premixed solution of $2 \mathrm{M}$ urea, $1 \mathrm{mM}$ calcium chloride, and $2 \mu \mathrm{g}$ trypsin in PBS, and incubated at $37^{\circ} \mathrm{C}$ overnight. The beads were pelleted by centrifugation and the supernatant, containing the peptide digests, was collected. The beads were washed twice with $50 \mu \mathrm{L}$ water and the collected supernatant fractions were combined. Formic acid $(15 \mu \mathrm{L})$ was added, and the samples were stored at $-20{ }^{\circ} \mathrm{C}$ until MS analysis.

Liquid Chromatography Mass Spectrometry Mass spectrometry was performed on an LTQ Orbitrap Discovery (Thermo Fisher) coupled to an Agilent 1200 series HPLC. Protein digests were pressure loaded onto a $250 \mu \mathrm{m}$ fused silica desalting column, packed with $4 \mathrm{~cm}$ Aqua C18 reverse phase resin (Phenomenex). Peptides were eluted onto a $100 \mu \mathrm{m}$ fused silica biphasic column, packed with $4 \mathrm{~cm}$ strong cation exchange resin (Watman) and $10 \mathrm{~cm} \mathrm{C18} \mathrm{resin} \mathrm{using} \mathrm{a} \mathrm{using} \mathrm{a} \mathrm{five-step} \mathrm{multidimensional} \mathrm{LC/LC-}$ MS/MS protocol (MudPIT) (1). Each of the five runs begins with a salt push $(0 \%, 25 \%, 50 \%, 80 \%$, and $100 \%$ buffer C), followed by a gradient $0-100 \%$ buffer B in buffer A (buffer A: $95 \%$ water, $5 \%$ acetonitrile, $0.1 \%$ formic acid; buffer B: $20 \%$ water, $80 \%$ acetonitrile, $0.1 \%$ formic acid; buffer C $95 \%$ water, $5 \%$ acetonitrile, $500 \mathrm{mM}$ ammonium acetate). The flowrate was $\sim 0.25 \mathrm{uL} / \mathrm{min}$ and the spray voltage was set to $2.75 \mathrm{kV}$. One full MS1 scan (400-1800 m/z) was followed by 8 data dependent scans of the $\mathrm{n}^{\text {th }}$ most intense ion.

Peptide Identification Peptides were assigned to MS2s using the SEQUEST (2) algorithm, searching against a human reverse-concatenated non-redundant protein database. Data sets were searched independently for peptides containing isotopically light and heavy amino acids. For the light search the default masses of lysine and arginine were used, for the heavy search a static modification was specified for lysine $(+8.0142 \mathrm{~m} / \mathrm{z})$ and arginine $(+10.00826 \mathrm{~m} / \mathrm{z})$. A static modification was specified for cysteine residues $(+57.0215 \mathrm{~m} / \mathrm{z}$, iodoacetamide alkylation) in both heavy and light samples. MS2 matches were filtered to achieve a false discovery rate of 5\% using DTASelect 2.0 (3).

Ratio Quantification Heavy/light intensity ratios $\left(\mathrm{R}_{\mathrm{H} / \mathrm{L}}\right)$ were quantified using the CIMAGE quantification package as described previously (1). CIMAGE reports peptide $\mathrm{R}_{\mathrm{H} / \mathrm{L}}$ for co-eluting light and heavy peptides. The peptides are grouped by protein and a representative $\mathrm{R}_{\mathrm{H} / \mathrm{L}}$ for each protein is calculated from the median $\mathrm{R}_{\mathrm{H} / \mathrm{L}}$ for each peptide identified for that protein.

Med25 labeling with Gibberelic Acid Derivatives The Activator Interaction Domain (AcID) of Med25, a transcriptional coactivator with three cysteines, was used to assess the irreversible labeling capacity of JRA-003. Med25 AcID (10 mM NaPO4, $100 \mathrm{mM} \mathrm{NaCl,} \mathrm{pH} \mathrm{6.8)} \mathrm{was} \mathrm{incubated} \mathrm{with} 1$ equivalent of JRA003 or JRA-002 for $12 \mathrm{~h}$. Labeling efficiency was determined using an Agilent Q-TOF HPLC-MS. Protein samples were injected onto the instrument and the small molecule/protein mixture separated via a Poroshell C8 column using a gradient of 5-100\% acetonitrile in water with $0.1 \%$ formic acid. Data was analyzed using the Agilent workstation software. Incubation with JRA-003 revealed complete conversion of 
unlabeled Med25 to mono-labeled and di-labeled Med25-kGAme covalent complexes. Conversely, incubation of Med25 with GA revealed no covalent modification of Med25. 


\section{Supplementary Information Section 3: Synthetic Procedures}

General Laboratory Procedures. All moisture-sensitive reactions were performed under an atmosphere of nitrogen in flame-dried round bottom flasks or glass vials fitted with rubber septa and/or septa equipped screw caps. Stainless steel syringes were used to transfer air or moisture-sensitive liquids. Flash chromatography was performed using silica gel Silia Flash ® 40-63 micron (230-400 mesh) from Silicycle.

Materials and Instrumentation. All chemicals were purchased from commercial suppliers and were used as received unless otherwise stated. Proton Nuclear Magnetic Resonance NMR ( ${ }^{1} \mathrm{H}$ NMR) spectra and carbon nuclear magnetic resonance $\left({ }^{13} \mathrm{C}\right.$ NMR) spectra were recorded on a Varian Unity Plus 400, Varian MR400, Varian vnmrs 500, Varian Inova 500, Varian Mercury 500, and Varian vnmrs 700 spectrometers. Chemical shifts for protons are reported in parts per million and are references to the NMR solvent peak $\left(\mathrm{CDCl}_{3}: \delta 7.26 \mathrm{ppm}\right)$. Chemical shifts for carbons are reported in parts per million and are referenced to the carbon resonances of the NMR solvent $\left(\mathrm{CDCl}_{3}: \delta 77.16 \mathrm{ppm}, \mathrm{CD}_{3} \mathrm{OD}: \delta 50.41 \mathrm{ppm}\right)$. Data are represented as follows: chemical shift, integration, multiplicity $(\mathrm{br}=$ broad, $\mathrm{s}=$ singlet, $\mathrm{d}=$ doublet, $\mathrm{t}=$ triplet, $\mathrm{q}=$ quartet, $\mathrm{p}=$ pentet, $\mathrm{m}=$ multiplet), and coupling constants in Hertz $(\mathrm{Hz})$. Mass spectroscopic (MS) data was recorded at the Mass Spectrometry Facility at the Department of Chemistry of the University of Michigan in Ann Arbor, MI on an Agilent Q-TOF HPLC-MS with ESI high resolution mass spectrometer. 
Gibberellins JRA-001, JRA-002, JRA-003, JRA-004, JRA-005, JRA-006, JRA-007, JRA-008, JRA009, JRA-010, JRA-011, JRA-012 were prepared according to literature procedures and spectral characterization matched those reported. ${ }^{4}$

JRA-013

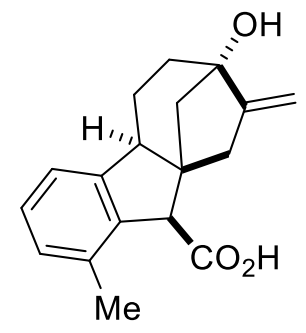

JRA-013

Gibberellic acid (JRA-001, $2 \mathrm{~g}$ ) was added to $65^{\circ} \mathrm{C} 1 \mathrm{M}$ hydrochloric acid (12 mL) and was held at $65{ }^{\circ} \mathrm{C}$ for $3 \mathrm{~h}$. The reaction was cooled to $20{ }^{\circ} \mathrm{C}$ and JRA-013 (1.2 g, 82\% yield) was filtered away as a white solid and the filtrate was washed with cold water before being dried in vacuo. A sample was purified by RP-HPLC on a Phenominex C18 column prior to biological screening. ${ }^{1} \mathbf{H}$ NMR $\left(401 \mathrm{MHz}, \mathrm{CDCl}_{3}\right) \delta 7.13(\mathrm{t}, J=7.4 \mathrm{~Hz}, 1 \mathrm{H}), 7.01(\mathrm{~d}, J=7.3 \mathrm{~Hz}, 1 \mathrm{H}), 6.93(\mathrm{~d}, J=7.5 \mathrm{~Hz}, 1 \mathrm{H}), 5.01$ $(\mathrm{d}, J=2.5 \mathrm{~Hz}, 1 \mathrm{H}), 4.78(\mathrm{~s}, 1 \mathrm{H}), 4.01(\mathrm{~s}, 1 \mathrm{H}), 2.90-2.79(\mathrm{~m}, 1 \mathrm{H}), 2.29-2.07(\mathrm{~m}, 6 \mathrm{H}), 2.00-1.88(\mathrm{~m}$, $2 \mathrm{H}), 1.73(\mathrm{~d}, J=11.6 \mathrm{~Hz}, 1 \mathrm{H}), 1.66-1.53(\mathrm{~m}, 2 \mathrm{H}), 1.24(\mathrm{~s}, 1 \mathrm{H}) .{ }^{13} \mathbf{C}$ NMR $\left(176 \mathrm{MHz}, \mathrm{CD}_{3} \mathrm{OD}\right) \delta 175.12$, $155.74,146.02$, 139.88, 136.26, 129.77, 128.34, 120.56, 103.54, 81.16, 56.04, 54.19, 53.34, 49.40, 40.71, 35.33, 23.13, 19.94. HRMS (ESI+): calculated for $\mathrm{C}_{18} \mathrm{H}_{20} \mathrm{O}_{3}[\mathrm{M}+\mathrm{Na}]^{+}: 307.1310$, found: 307.1313.

\section{JRA-014}

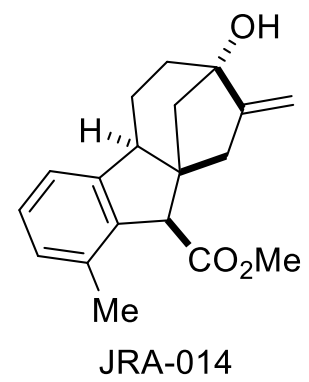

JRA-002 (200 mg) was added to $65^{\circ} \mathrm{C} 1 \mathrm{M}$ hydrochloric acid $(2 \mathrm{~mL})$ and was held at $65{ }^{\circ} \mathrm{C}$ for 3 h. The reaction was cooled to $20{ }^{\circ} \mathrm{C}$ and JRA-014 (150 mg, 91\% yield) was filtered away as a white solid and the filtrate was washed with cold water before being dried in vacuo. A sample was purified by RP-HPLC on a Phenominex C18 column prior to biological screening. ${ }^{\mathbf{1}} \mathbf{H}$ NMR (700 $\left.\mathrm{MHz} \mathrm{CDCl}_{3}\right) \delta 7.13(\mathrm{t}, J=7.4 \mathrm{~Hz}, 1 \mathrm{H}), 7.01(\mathrm{~d}, J=7.5 \mathrm{~Hz}, 1 \mathrm{H}), 6.94(\mathrm{~d}, J=7.2 \mathrm{~Hz}, 1 \mathrm{H}), 5.00(\mathrm{~s}, 1 \mathrm{H})$, $4.78(\mathrm{~s}, 1 \mathrm{H}), 3.98(\mathrm{~s}, 1 \mathrm{H}), 3.77(\mathrm{~s}, 3 \mathrm{H}), 2.83(\mathrm{~d}, J=10.8 \mathrm{~Hz}, 1 \mathrm{H}), 2.26-2.22(\mathrm{~m}, 1 \mathrm{H}), 2.17(\mathrm{~d}, J=16.4 \mathrm{~Hz}$, $6 \mathrm{H}), 1.99-1.91(\mathrm{~m}, 2 \mathrm{H}), 1.73(\mathrm{~d}, J=11.4 \mathrm{~Hz}, 1 \mathrm{H}), 1.61(\mathrm{~d}, J=12.3 \mathrm{~Hz}, 2 \mathrm{H}) .{ }^{13} \mathbf{C} \mathbf{N M R}\left(176 \mathrm{MHz}, \mathrm{CDCl}_{3}\right)$ $\delta 171.80,154.37,144.35,138.27,134.98,128.94,127.41,119.69,103.23,80.55,54.74,53.38,52.06$, 51.75, 48.80, 39.35, 34.17, 21.99, 19.67. HRMS (ESI+): calculated for $\mathrm{C}_{19} \mathrm{H}_{22} \mathrm{O}_{3}[\mathrm{M}+\mathrm{Na}]^{+}: 321.1467$, found: 321.1471 . 


\section{JRA-015 and JRA-028}
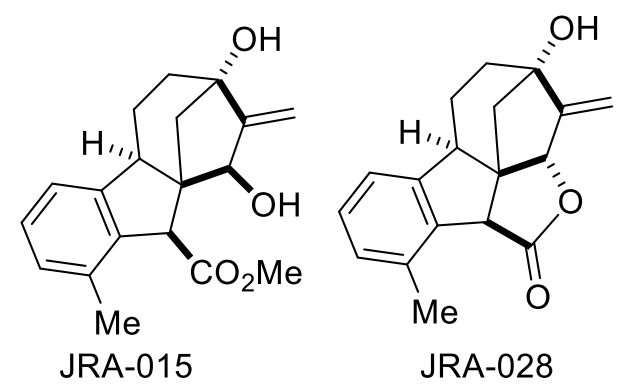

JRA-014 (90 mg) and selenium dioxide (37 mg $1.1 \mathrm{eq}$ ) was dissolved in tetrahydrofuran (3 mL). tert-Butyl hydrogenperoxide $(0.165 \mathrm{~mL}, 5.5 \mathrm{M}$ in decane, $3 \mathrm{eq})$ was added and the reaction was allowed to stir for 2 $\mathrm{h}$. The crude reaction mixture was concentrated, and then resuspended in water $(5 \mathrm{~mL})$. The resulting mixture was sonicated at $10{ }^{\circ} \mathrm{C}$ for 10 minutes, and extracted with ethyl acetate. The combined extracts were washed with brine, dried over sodium sulfate, and concentrated. JRA-015 (35 mg, 37\% yield) and JRA-028 (30 mg, 35\% yield) were isolated as white solids after gradient chromatographic separation on silica gel (ethyl acetate/hexanes). A sample of each was purified by RP-HPLC on a Phenominex C18 column prior to biological screening.

JRA-015 ${ }^{1} \mathbf{H}$ NMR $\left(700 \mathrm{MHz}, \mathrm{CDCl}_{3}\right) \delta 7.15(\mathrm{t}, J=7.4 \mathrm{~Hz}, 1 \mathrm{H}), 6.83(\mathrm{~d}, J=7.9 \mathrm{~Hz}, 1 \mathrm{H}), 6.76(\mathrm{~d}, J=8.2$ $\mathrm{Hz}, 1 \mathrm{H}), 5.51(\mathrm{~s}, 1 \mathrm{H}), 5.45(\mathrm{~s}, 1 \mathrm{H}), 4.92(\mathrm{~s}, 1 \mathrm{H}), 4.71(\mathrm{~s}, 1 \mathrm{H}), 3.74(\mathrm{~s}, 1 \mathrm{H}), 3.64(\mathrm{~s}, 3 \mathrm{H}), 2.87(\mathrm{~s}, 1 \mathrm{H}), 2.19$ $(\mathrm{s}, 3 \mathrm{H}), 2.07(\mathrm{~d}, J=14.4 \mathrm{~Hz}, 1 \mathrm{H}), 1.98-1.90(\mathrm{~m}, 1 \mathrm{H}), 1.82(\mathrm{~d}, J=11.2 \mathrm{~Hz}, 1 \mathrm{H}), 1.72(\mathrm{dd}, J=12.7,6.1$ $\mathrm{Hz}, 1 \mathrm{H}), 1.62(\mathrm{t}, J=15.6 \mathrm{~Hz}, 3 \mathrm{H}) .{ }^{13} \mathbf{C}$ NMR $\left(176 \mathrm{MHz}, \mathrm{CDCl}_{3}\right) \delta 175.19,157.33,150.93,138.37,128.68$, 123.11, 117.62, 115.08, 110.66, 97.66, 78.09, 73.61, 53.11, 51.04, 44.99, 42.80, 35.96, 34.50, 19.23. HRMS (ESI+): calculated for $\mathrm{C}_{19} \mathrm{H}_{22} \mathrm{O}_{4}[\mathrm{M}+\mathrm{H}]^{+}: 315.1596$, found: 315.1604 .

JRA-028 ${ }^{1} \mathbf{H}$ NMR $\left(700 \mathrm{MHz}, \mathrm{CDCl}_{3}\right) \delta 7.22(\mathrm{t}, J=7.4 \mathrm{~Hz}, 1 \mathrm{H}), 7.09(\mathrm{~d}, J=7.3 \mathrm{~Hz}, 1 \mathrm{H}), 7.02(\mathrm{~d}, J=7.3$ $\mathrm{Hz}, 1 \mathrm{H}), 5.44(\mathrm{~s}, 1 \mathrm{H}), 5.35(\mathrm{~s}, 1 \mathrm{H}), 4.53(\mathrm{~s}, 1 \mathrm{H}), 3.97(\mathrm{~s}, 1 \mathrm{H}), 3.10-3.05(\mathrm{~m}, 1 \mathrm{H}), 2.44(\mathrm{~s}, 3 \mathrm{H}), 2.39-2.33$ $(\mathrm{m}, 1 \mathrm{H}), 2.19(\mathrm{~d}, J=10.6 \mathrm{~Hz}, 1 \mathrm{H}), 2.03(\mathrm{dd}, J=12.9,7.9 \mathrm{~Hz}, 1 \mathrm{H}), 1.93(\mathrm{~d}, J=10.5 \mathrm{~Hz}, 1 \mathrm{H}), 1.84(\mathrm{~d}, J=$ $16.1 \mathrm{~Hz}, 2 \mathrm{H}), 1.48-1.40(\mathrm{~m}, 1 \mathrm{H}) .{ }^{13} \mathbf{C} \mathbf{N M R}\left(176 \mathrm{MHz}, \mathrm{CDCl}_{3}\right) \delta 174.82,150.77,144.40,137.57,134.73$, $129.85,128.95,121.28,111.57,81.94,81.83,56.59,52.90,47.87,43.84,38.40,23.09$, 19.46. HRMS (ESI+): calculated for $\mathrm{C}_{18} \mathrm{H}_{18} \mathrm{O}_{3}[\mathrm{M}+\mathrm{Na}]^{+}: 305.1154$, found: 305.1164 . 


\section{JRA-017}

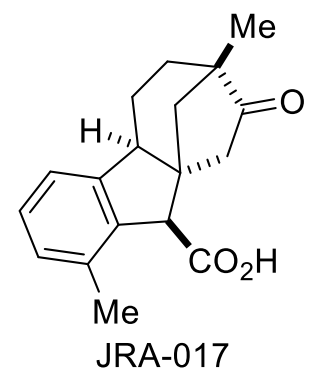

Gibberellic acid (JRA-001 $2 \mathrm{~g}$ ) was dissolved in $2 \mathrm{M}$ hydrochloric acid (20 $\mathrm{mL})$ and the solution was heated at reflux for $2 \mathrm{~h}$. The reaction mixture was cooled $20{ }^{\circ} \mathrm{C}$ and JRA-017 $(800 \mathrm{mg}, 49 \%$ yield) was filtered from the reaction mixture as a white solid, washed with cold water and dried in vacuo. A sample was purified by RP-HPLC on a Phenominex C18 column prior to biological screening. ${ }^{1} \mathbf{H}$ NMR $\left(401 \mathrm{MHz}, \mathrm{CDCl}_{3}\right) \delta 7.22(\mathrm{t}, J=7.6 \mathrm{~Hz}, 1 \mathrm{H}), 7.07(\mathrm{~d}, J=7.5 \mathrm{~Hz}, 1 \mathrm{H}), 7.00(\mathrm{~d}, J=$ $7.4 \mathrm{~Hz}, 1 \mathrm{H}), 4.21(\mathrm{~s}, 1 \mathrm{H}), 3.04(\mathrm{t}, J=7.7 \mathrm{~Hz}, 1 \mathrm{H}), 2.74(\mathrm{~d}, J=17.8 \mathrm{~Hz}, 1 \mathrm{H}), 2.51(\mathrm{dd}, J=17.7,3.4 \mathrm{~Hz}$, $1 \mathrm{H}), 2.25(\mathrm{~s}, 3 \mathrm{H}), 2.14-2.02(\mathrm{~m}, 2 \mathrm{H}), 1.94-1.85(\mathrm{~m}, 1 \mathrm{H}), 1.77(\mathrm{dd}, J=14.4,7.0 \mathrm{~Hz}, 1 \mathrm{H}), 1.65(\mathrm{dd}, J=$ 13.2, $6.5 \mathrm{~Hz}, 2 \mathrm{H}), 1.39(\mathrm{~d}, J=11.9 \mathrm{~Hz}, 1 \mathrm{H}), 1.07(\mathrm{~s}, 3 \mathrm{H}) .{ }^{13} \mathbf{C}$ NMR $\left(176 \mathrm{MHz}, \mathrm{CDCl}_{3}\right) \delta 221.46,175.08$, $146.17,137.11,135.36,129.18,128.55,120.58,55.42,51.28,50.62,49.92,48.17,39.03,34.48,22.88$, 21.69, 19.68. HRMS (ESI+): calculated for $\mathrm{C}_{18} \mathrm{H}_{20} \mathrm{O}_{3}[\mathrm{M}+\mathrm{Na}]^{+}:$307.1310, found: 307.1304 .

\section{JRA-018}

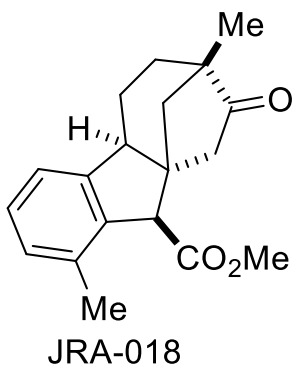

JRA-014 (300 mg) was dissolved in toluene $(50 \mathrm{~mL})$ to which was added p-toluenesulfonic acid (574 mg, $3 \mathrm{eq}$ ) and the reaction was heated to reflux for $30 \mathrm{~min}$. The reaction was cooled to $20{ }^{\circ} \mathrm{C}$ and quenched with saturated aqueous sodium bicarbonate. The organic layer was separated, and the aqueous layer was extracted with ethyl acetate. The combined organic layers were washed with saturated aqueous sodium bicarbonate and brine, dried over sodium sulfate and concentrated. JRA028 (250 mg, 83\% yield) was isolated as a white solid after gradient chromatographic separation on silica gel (ethyl acetate/hexanes). A sample of each was purified by RP-HPLC on a Phenominex C18 column prior to biological screening. ${ }^{1} \mathbf{H}$ NMR $\left(401 \mathrm{MHz}, \mathrm{CDCl}_{3}\right) \delta 7.20(\mathrm{t}, J=7.6 \mathrm{~Hz}, 1 \mathrm{H}), 7.06$ $(\mathrm{d}, J=7.5 \mathrm{~Hz}, 1 \mathrm{H}), 6.99(\mathrm{~d}, J=7.4 \mathrm{~Hz}, 1 \mathrm{H}), 4.17(\mathrm{~s}, 1 \mathrm{H}), 3.78(\mathrm{~s}, 2 \mathrm{H}), 3.01(\mathrm{t}, J=7.8 \mathrm{~Hz}, 1 \mathrm{H}), 2.68(\mathrm{~d}, J$ $=17.9 \mathrm{~Hz}, 1 \mathrm{H}), 2.48(\mathrm{dd}, J=17.9,3.6 \mathrm{~Hz}, 1 \mathrm{H}), 2.17(\mathrm{~s}, 2 \mathrm{H}), 2.12-2.04(\mathrm{~m}, 1 \mathrm{H}), 2.02(\mathrm{dd}, J=12.0,3.6$ $\mathrm{Hz}, 1 \mathrm{H}), 1.94-1.84(\mathrm{~m}, 1 \mathrm{H}), 1.82-1.72(\mathrm{~m}, 1 \mathrm{H}), 1.67-1.60(\mathrm{~m}, 1 \mathrm{H}), 1.20(\mathrm{~d}, J=12.0 \mathrm{~Hz}, 1 \mathrm{H}), 1.05(\mathrm{~s}$, 2H). ${ }^{13} \mathbf{C}$ NMR $\left(176 \mathrm{MHz}, \mathrm{CDCl}_{3}\right) \delta 221.73,172.37,146.10,137.69,135.30,129.07,128.31,120.52,56.02$, 52.01, 51.20, 50.72, 50.06, 48.13, 39.08, 34.51, 22.94, 21.70, 19.51. HRMS (ESI+): calculated for $\mathrm{C}_{19} \mathrm{H}_{22} \mathrm{O}_{3}[\mathrm{M}+\mathrm{Na}]^{+}:$321.1467, found: 321.1469. 


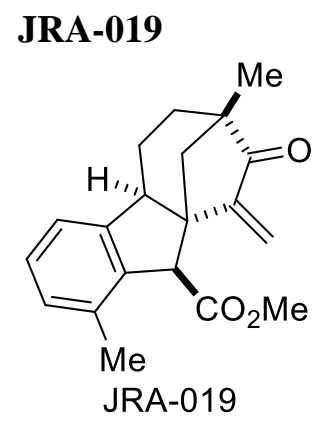

JRA-018 (27.1 mg) was dissolved in tetrahydrofuran $(2 \mathrm{~mL})$ and cooled to $-78{ }^{\circ} \mathrm{C}$. A freshly prepared LDA solution $(0.5 \mathrm{M}$ in tetrahydrofuran, $0.182 \mathrm{~mL}, 1 \mathrm{eq})$ was added dropwise and the reaction was allowed to stir for $30 \mathrm{~min}$. At which point Eschenmoser's salt was added as a solution $(0.5 \mathrm{M}$ in tetrahydrofuran, $0.363 \mathrm{~mL}, 2 \mathrm{eq})$ to the resultant lithium enolate. The reaction was allowed to come to room temperature over $60 \mathrm{~min}$, quenched with saturated aqueous sodium bicarbonate, and extracted with ether. The combined extracts were washed with saturated aqueous sodium bicarbonate and brine, dried over magnesium sulfate, and concentrated. The crude concentrate $(26.1 \mathrm{mg})$ was dissolved in tetrahydrofuran $(2 \mathrm{~mL})$ and iodomethane $(0.022 \mathrm{~mL}, 4 \mathrm{eq})$ was added. The reaction was allowed to stir at $20{ }^{\circ} \mathrm{C}$ for $8 \mathrm{~h}$. Then DBU $(0.024 \mathrm{~mL}, 2 \mathrm{eq})$ was added and the reaction was heated at reflux for $90 \mathrm{~min}$. The reaction was cooled to $20^{\circ} \mathrm{C}$, quenched with saturated aqueous ammonium chloride, and extracted with ether. The combined extracts were washed with brine, dried over magnesium sulfate, and concentrated. JRA-019 (19 mg, 67\% yield) was purified by gradient column chromatography over silica (ethyl acetate/hexanes). Samples were purified by HPLC on a Phenomenex RPC18 column before being subjected to biological evaluations. ${ }^{1} \mathbf{H}$ NMR $\left(401 \mathrm{MHz}, \mathrm{CDCl}_{3}\right) \delta 7.22(\mathrm{t}, J=7.5 \mathrm{~Hz}, 4 \mathrm{H}), 7.07(\mathrm{~d}, J=7.5 \mathrm{~Hz}, 3 \mathrm{H}), 6.97(\mathrm{~d}, J=7.4 \mathrm{~Hz}, 3 \mathrm{H}), 6.11$ $(\mathrm{s}, 3 \mathrm{H}), 5.43(\mathrm{~s}, 3 \mathrm{H}), 4.44(\mathrm{~s}, 3 \mathrm{H}), 3.80(\mathrm{ddd}, J=13.8,8.8,4.1 \mathrm{~Hz}, 5 \mathrm{H}), 3.76-3.72(\mathrm{~m}, 9 \mathrm{H}), 3.07(\mathrm{t}, J=$ $7.8 \mathrm{~Hz}, 3 \mathrm{H}), 2.19(\mathrm{~d}, J=9.0 \mathrm{~Hz}, 9 \mathrm{H}), 2.13-2.03(\mathrm{~m}, 9 \mathrm{H}), 1.96-1.88(\mathrm{~m}, 4 \mathrm{H}), 1.79(\mathrm{dd}, J=14.9,8.3 \mathrm{~Hz}$, $4 \mathrm{H}), 1.72-1.65(\mathrm{~m}, 4 \mathrm{H}), 1.17(\mathrm{dd}, J=12.8,8.6 \mathrm{~Hz}, 6 \mathrm{H}), 1.11(\mathrm{~s}, 9 \mathrm{H}) .{ }^{13} \mathbf{C}$ NMR $\left(176 \mathrm{MHz}, \mathrm{CDCl}_{3}\right) \delta$ 210.49, 172.14, 150.60, 145.19, 137.61, 135.29, 129.23, 128.48, 120.55, 114.12, 55.48, 54.26, 53.37, 52.06, 45.93, 37.37, 34.21, 22.82, 21.50, 19.42. HRMS (ESI+): calculated for $\mathrm{C}_{20} \mathrm{H}_{22} \mathrm{O}_{3}[\mathrm{M}+\mathrm{H}]^{+}: 311.1647$, found: 311.1652 . 


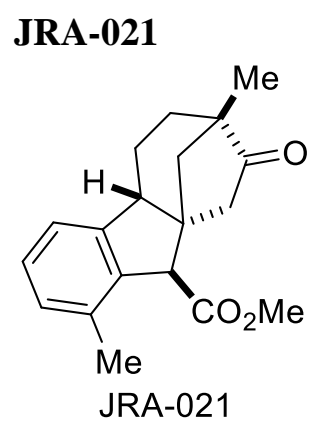

JRA-004 (180 mg) was dissolved in dichloromethane $(6 \mathrm{~mL})$ at cooled to $-78{ }^{\circ} \mathrm{C}$. Triethylamine $(0.798 \mathrm{~mL}$, 10 eq) was added, the reaction was allowed to stir for $15 \mathrm{~min}$ and triflic anhydride $(0.144 \mathrm{~mL}, 1.5 \mathrm{eq})$ was added and the reaction was allowed to stir for $2 \mathrm{~h}$. The reaction was quenched, cold, with saturated aqueous sodium bicarbonate, allowed to come to room temperature, and extracted with dichloromethane. The combined organic layers were washed with saturated aqueous ammonium carbonate, and brine, dried over sodium sulfate, and concentrated to dryness. The crude triflate $(198 \mathrm{mg})$ was redissolved in DMF (4 mL) to which was added palladium (II) acetate $(6.4 \mathrm{mg}), 1,1$ '-Bis(diphenylphosphino)ferrocene (31 $\mathrm{mg}$ ), Hünig's base $(0.144 \mathrm{~mL})$ and formic acid $(0.021 \mathrm{~mL})$. The reaction was heated to $100{ }^{\circ} \mathrm{C}$ for $10 \mathrm{~h}$. The reaction was allowed to come to room temperature, quenched with $5 \%(\mathrm{w} / \mathrm{v})$ aqueous lithium chloride, and extracted with ethyl acetate. The combined organic layers were washed with 5\% (w/v) aqueous lithium chloride, dried over sodium sulfate and concentrated. JRA-021 (70 mg, 30\% yield) was isolated as a white solid after gradient column chromatography over silica (ethyl acetate/hexanes). Samples were purified by HPLC on a Phenomenex RPC18 column before being subjected to biological evaluations. ${ }^{1} \mathbf{H}$ NMR (401 $\left.\mathrm{MHz}, \mathrm{CDCl}_{3}\right) \delta 7.16(\mathrm{t}, J=7.4 \mathrm{~Hz}, 10 \mathrm{H}), 7.01(\mathrm{~d}, J=7.2 \mathrm{~Hz}, 8 \mathrm{H}), 6.96(\mathrm{~d}, J=7.1 \mathrm{~Hz}, 8 \mathrm{H}), 3.74(\mathrm{~s}, 7 \mathrm{H})$, $3.71(\mathrm{~s}, 19 \mathrm{H}), 3.53(\mathrm{dd}, J=12.3,5.1 \mathrm{~Hz}, 9 \mathrm{H}), 2.27(\mathrm{~d}, J=13.6 \mathrm{~Hz}, 28 \mathrm{H}), 2.19(\mathrm{~d}, J=3.7 \mathrm{~Hz}, 5 \mathrm{H}), 2.09-$ $2.01(\mathrm{~m}, 15 \mathrm{H}), 1.98(\mathrm{~d}, J=3.9 \mathrm{~Hz}, 8 \mathrm{H}), 1.64(\mathrm{dd}, J=13.6,6.0 \mathrm{~Hz}, 15 \mathrm{H}), 1.46(\mathrm{dd}, J=12.9,5.6 \mathrm{~Hz}, 9 \mathrm{H})$, $1.11(\mathrm{~s}, 19 \mathrm{H}) .{ }^{13} \mathrm{C}$ NMR $\left(176 \mathrm{MHz}, \mathrm{CDCl}_{3}\right) \delta 219.14,172.01,166.35,145.30,139.00,134.70,128.33$, 128.22, 120.54, 77.48, 76.86, 56.38, 51.94, 50.92, 49.53, 48.75, 44.70, 36.80, 22.55. HRMS (ESI+): calculated for $\mathrm{C}_{19} \mathrm{H}_{22} \mathrm{O}_{3}[\mathrm{M}+\mathrm{Na}]^{+}: 321.1467$, found: 321.1474 . 


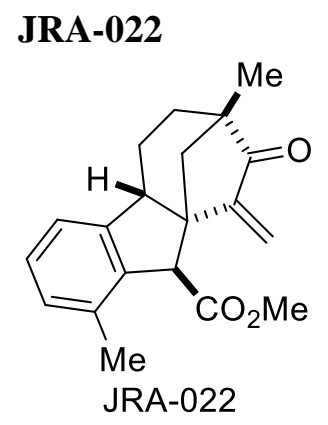

JRA-021 (21.0 mg) was dissolved in tetrahydrofuran $(2 \mathrm{~mL})$ and cooled to $-78{ }^{\circ} \mathrm{C}$. A freshly prepared LDA solution $(0.5 \mathrm{M}$ in tetrahydrofuran, $0.141 \mathrm{~mL}, 1 \mathrm{eq})$ was added dropwise and the reaction was allowed to stir for $30 \mathrm{~min}$. At which point Eschenmoser's salt was added as a solution $(0.5 \mathrm{M}$ in tetrahydrofuran, 0.282 $\mathrm{mL}, 2$ eq) to the resultant lithium enolate. The reaction was allowed to come to room temperature over 60 min, quenched with saturated aqueous sodium bicarbonate, and extracted with ether. The combined extracts were washed with saturated aqueous sodium bicarbonate and brine, dried over magnesium sulfate, and concentrated. The crude concentrate $(26.1 \mathrm{mg})$ was dissolved in tetrahydrofuran $(2 \mathrm{~mL})$ and iodomethane $(0.018 \mathrm{~mL}, 4 \mathrm{eq})$ was added. The reaction was allowed to stir at $20^{\circ} \mathrm{C}$ for $8 \mathrm{~h}$. Then DBU $(0.018 \mathrm{~mL}, 2 \mathrm{eq})$ was added and the reaction was heated at reflux for $90 \mathrm{~min}$. The reaction was cooled to $20{ }^{\circ} \mathrm{C}$, quenched with saturated aqueous ammonium chloride, and extracted with ether. The combined extracts were washed with brine, dried over magnesium sulfate, and concentrated. JRA-022 (14 mg, 64\% yield) was purified by gradient column chromatography over silica (ethyl acetate/hexanes). Samples were purified by HPLC on a Phenomenex RPC18 column before being subjected to biological evaluations. ${ }^{1} \mathbf{H}$ NMR $\left(700 \mathrm{MHz}, \mathrm{CDCl}_{3}\right)$ $\delta 7.16(\mathrm{t}, J=7.3 \mathrm{~Hz}, 4 \mathrm{H}), 7.02(\mathrm{~d}, J=7.3 \mathrm{~Hz}, 3 \mathrm{H}), 6.90(\mathrm{~d}, J=7.3 \mathrm{~Hz}, 3 \mathrm{H}), 5.82(\mathrm{~s}, 3 \mathrm{H}), 4.52(\mathrm{~s}, 3 \mathrm{H}), 3.94$ $(\mathrm{s}, 3 \mathrm{H}), 3.72(\mathrm{~s}, 10 \mathrm{H}), 3.68(\mathrm{~d}, J=12.3 \mathrm{~Hz}, 4 \mathrm{H}), 2.32(\mathrm{~s}, 9 \mathrm{H}), 2.22-2.19(\mathrm{~m}, 4 \mathrm{H}), 2.03(\mathrm{~d}, J=10.8 \mathrm{~Hz}$, 4H), $1.97(\mathrm{~d}, J=11.1 \mathrm{~Hz}, 4 \mathrm{H}), 1.78(\mathrm{~d}, J=8.9 \mathrm{~Hz}, 4 \mathrm{H}), 1.73(\mathrm{~d}, J=8.1 \mathrm{~Hz}, 4 \mathrm{H}), 1.38(\mathrm{~d}, J=14.1 \mathrm{~Hz}, 4 \mathrm{H})$, $1.17(\mathrm{~s}, 10 \mathrm{H}) .{ }^{13} \mathrm{C}$ NMR $\left(176 \mathrm{MHz}, \mathrm{CDCl}_{3}\right) \delta 207.99,171.62,149.97,144.48,139.25,133.83,128.28$, $128.10,120.66,115.74,56.05,54.36,52.34,51.90,48.82,43.49,37.07,23.17,19.83,18.85$. HRMS (ESI+): calculated for $\mathrm{C}_{20} \mathrm{H}_{22} \mathrm{O}_{3}[\mathrm{M}+\mathrm{Na}]^{+}: 331.1467$, found: 331.1466 . 


\section{JRA-023}

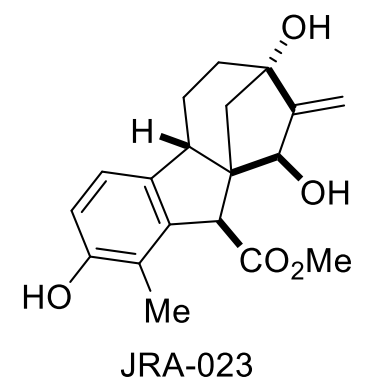

JRA-004 (85 mg) and selenium dioxide (30 mg $1.1 \mathrm{eq})$ was dissolved in dichloromethane $(10 \mathrm{~mL})$. tertButyl hydrogenperoxide $(0.406 \mathrm{~mL}, 4.5 \mathrm{M}$ in decane, $3 \mathrm{eq})$ was added and the reaction was allowed to stir for $2 \mathrm{~h}$. The crude reaction mixture was concentrated, and then resuspended in water $(5 \mathrm{~mL})$. The resulting mixture was sonicated at $10{ }^{\circ} \mathrm{C}$ for 10 minutes and extracted with ethyl acetate. The combined extracts were washed with brine, dried over sodium sulfate, and concentrated. JRA-023 (40 mg, 45\% yield) was isolated as a white solid after gradient chromatographic separation on silica gel (ethyl acetate/hexanes). A sample was purified by RP-HPLC on a Phenominex C18 column prior to biological screening. ${ }^{1} \mathbf{H}$ NMR $(401 \mathrm{MHz}$, $\left.\mathrm{CDCl}_{3}\right) \delta 6.85(\mathrm{~d}, J=7.8 \mathrm{~Hz}, 3 \mathrm{H}), 6.69(\mathrm{~d}, J=8.0 \mathrm{~Hz}, 3 \mathrm{H}), 5.49(\mathrm{~s}, 3 \mathrm{H}), 5.45(\mathrm{~s}, 3 \mathrm{H}), 4.58(\mathrm{~s}, 3 \mathrm{H}), 3.81(\mathrm{~s}$, $3 \mathrm{H}), 3.69(\mathrm{~s}, 8 \mathrm{H}), 3.32(\mathrm{~d}, J=7.4 \mathrm{~Hz}, 3 \mathrm{H}), 2.19(\mathrm{~s}, 8 \mathrm{H}), 2.11(\mathrm{~d}, J=11.9 \mathrm{~Hz}, 4 \mathrm{H}), 2.04(\mathrm{~d}, J=9.9 \mathrm{~Hz}, 4 \mathrm{H})$, $1.86-1.76(\mathrm{~m}, 10 \mathrm{H}), 1.72(\mathrm{dd}, J=10.4,5.8 \mathrm{~Hz}, 8 \mathrm{H}), 1.42(\mathrm{~d}, J=9.6 \mathrm{~Hz}, 3 \mathrm{H}) .{ }^{13} \mathrm{C} \mathrm{NMR}(176 \mathrm{MHz}$, $\left.\mathrm{CDCl}_{3}\right) \delta 173.41,159.32,152.76,140.67,137.80,122.09,120.33,114.25,112.21,77.94,76.43,60.13$, 54.01, 52.37, 45.16, 44.83, 37.77, 21.14, 12.34. HRMS (ESI+): calculated for $\mathrm{C}_{19} \mathrm{H}_{22} \mathrm{O}_{5}[\mathrm{M}+\mathrm{Na}]^{+}$: 353.1365 , found: 353.1369 . 


\section{JRA-026 and JRA-029}

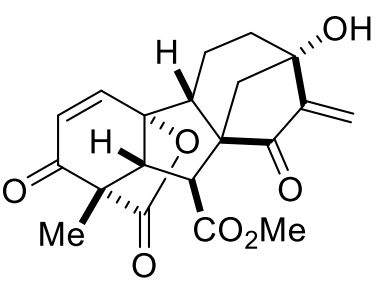

JRA-026

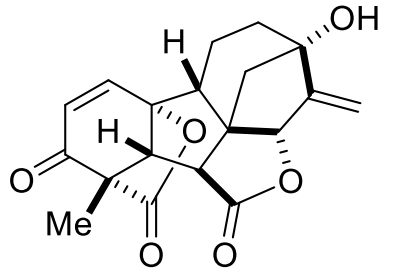

JRA-029

JRA-002 (687 mg) and selenium dioxide (212 mg, 2 eq) were dissolved in dichloromethane (30 mL) and tert-butyl hydroperoxide $(5.5 \mathrm{M}$ in decane, $1.56 \mathrm{~mL}, 4.5 \mathrm{eq})$ was added. The reaction was allowed to proceed for $2 \mathrm{~h}$ at $20^{\circ} \mathrm{C}$ before being concentrated. Water was added and the suspension was sonicated for $10 \mathrm{~min}$ at $10^{\circ} \mathrm{C}$. The suspension was extracted with ethyl acetate, the combined extracts were washed with brine, dried over sodium sulfate and concentrated. The crude mixture $(300 \mathrm{mg}$ ) was redissolved in dichloromethane $(10 \mathrm{~mL})$ and sodium bicarbonate $(699 \mathrm{mg})$ and Dess-Martin Periodinane (1.06 g) was added. The reaction was allowed to stir for $4 \mathrm{~h}$ at $20^{\circ} \mathrm{C}$ before being quenched by saturated aqueous sodium thiosulfate. The layers were separated, and the aqueous layer was extracted with dichloromethane. The combined organic extracts were washed with saturated aqueous sodium bicarbonate and brine, dried over sodium sulfate, and concentrated. JRA-026 (72 mg, 23\% yield) and JRA-028 (66 mg, 23\% yield) were isolated as white solids after gradient chromatographic separation on silica gel (ethyl acetate/hexanes). A sample of each was purified by RP-HPLC on a Phenominex C18 column prior to biological screening.

JRA-026 ${ }^{1} \mathbf{H}$ NMR $\left(401 \mathrm{MHz}, \mathrm{CDCl}_{3}\right) \delta 7.20(\mathrm{~d}, J=9.4 \mathrm{~Hz}, 1 \mathrm{H}), 6.13(\mathrm{~s}, 1 \mathrm{H}), 6.08(\mathrm{~d}, J=9.5 \mathrm{~Hz}, 1 \mathrm{H})$, $5.70(\mathrm{~s}, 1 \mathrm{H}), 3.67(\mathrm{~s}, 1 \mathrm{H}), 3.64(\mathrm{~s}, 3 \mathrm{H}), 2.83(\mathrm{~d}, J=10.3 \mathrm{~Hz}, 1 \mathrm{H}), 2.55(\mathrm{~d}, J=11.2 \mathrm{~Hz}, 1 \mathrm{H}), 2.27(\mathrm{~d}, J=$ $12.6 \mathrm{~Hz}, 3 \mathrm{H}), 2.16(\mathrm{~d}, J=11.2 \mathrm{~Hz}, 1 \mathrm{H}), 1.89(\mathrm{~d}, J=7.2 \mathrm{~Hz}, 2 \mathrm{H}), 1.35(\mathrm{~s}, 3 \mathrm{H}) .{ }^{13} \mathbf{C ~ N M R}\left(176 \mathrm{MHz}, \mathrm{CDCl}_{3}\right)$ $\delta 202.27,191.26,172.97,170.57,152.67,146.04,129.75,118.55,89.29,76.05,65.60,61.64,60.86,52.46$, 48.97, 48.09, 40.42, 36.72, 17.62, 12.04. HRMS (ESI+): calculated for $\mathrm{C}_{20} \mathrm{H}_{20} \mathrm{O}_{7}[\mathrm{M}+\mathrm{Na}]^{+}: 395.1107$, found: 395.1106 .

JRA-029 ${ }^{1} \mathbf{H}$ NMR $\left(700 \mathrm{MHz}, \mathrm{CDCl}_{3}\right) \delta 7.28(\mathrm{~s}, 1 \mathrm{H}), 6.11(\mathrm{~d}, J=9.5 \mathrm{~Hz}, 1 \mathrm{H}), 5.48(\mathrm{~s}, 1 \mathrm{H}), 5.36(\mathrm{~s}, 1 \mathrm{H})$, $4.66(\mathrm{~s}, 1 \mathrm{H}), 3.30(\mathrm{~d}, J=8.3 \mathrm{~Hz}, 1 \mathrm{H}), 2.84(\mathrm{~d}, J=8.5 \mathrm{~Hz}, 1 \mathrm{H}), 2.33(\mathrm{~d}, J=11.2 \mathrm{~Hz}, 1 \mathrm{H}), 2.24(\mathrm{dd}, J=11.9$, $5.2 \mathrm{~Hz}, 1 \mathrm{H}), 2.18(\mathrm{dd}, J=14.4,5.9 \mathrm{~Hz}, 1 \mathrm{H}), 2.06(\mathrm{dd}, J=12.6,6.5 \mathrm{~Hz}, 1 \mathrm{H}), 1.86-1.74(\mathrm{~m}, 4 \mathrm{H}), 1.54(\mathrm{~s}$, $3 \mathrm{H}) .{ }^{13} \mathbf{C}$ NMR $\left(176 \mathrm{MHz}, \mathrm{CDCl}_{3}\right) \delta 190.91,175.01,172.58,152.26,145.38,130.12,110.44,92.21,88.80$, 78.61, 65.03, 62.63, 54.18, 51.13, 50.73, 39.32, 36.54, 17.44, 12.32. HRMS (ESI+): calculated for $\mathrm{C}_{19} \mathrm{H}_{18} \mathrm{O}_{6}[\mathrm{M}+\mathrm{Na}]^{+}:$365.1001, found: 365.1002. 


\section{JRA-027}

(1)

JRA-027

JRA-002 (200 mg) and selenium dioxide (61.6 mg, $1.0 \mathrm{eq})$ were dissolved in dichloromethane (20 mL) and tetr-butyl hydroperoxide $(5.5 \mathrm{M}$ in decanes, $0.454 \mathrm{~mL}, 4.5 \mathrm{eq})$ was added. The reaction was allowed to stir at $20^{\circ} \mathrm{C}$ for $2 \mathrm{~h}$. The reaction was concentrated, water was added and the suspension was sonicated at $10{ }^{\circ} \mathrm{C}$ for 10 minutes. The mixture was extracted with dichloromethane, the combined extracts were washed with saturated aqueous sodium bcarbonate and brine, dried over sodium sulfate and concentrated. JRA-023 (66 mg, 32\% yield) was isolated as a white solid after gradient chromatographic separation on silica gel (ethyl acetate/hexanes). A sample was purified by RP-HPLC on a Phenominex C18 column prior to biological screening. ${ }^{1} \mathbf{H}$ NMR $\left(700 \mathrm{MHz}, \mathrm{CDCl}_{3}\right) \delta 6.32(\mathrm{~d}, J=9.3 \mathrm{~Hz}, 2 \mathrm{H}), 5.90(\mathrm{~d}, J=9.2 \mathrm{~Hz}, 2 \mathrm{H})$, $5.47(\mathrm{~s}, 2 \mathrm{H}), 5.39(\mathrm{~s}, 2 \mathrm{H}), 4.21(\mathrm{~s}, 2 \mathrm{H}), 4.18-4.14(\mathrm{~m}, 2 \mathrm{H}), 3.69(\mathrm{~s}, 6 \mathrm{H}), 3.18(\mathrm{~d}, J=10.2 \mathrm{~Hz}, 2 \mathrm{H}), 2.72(\mathrm{~d}, J=10.3$ $\mathrm{Hz}, 2 \mathrm{H}), 2.27(\mathrm{~d}, J=11.0 \mathrm{~Hz}, 2 \mathrm{H}), 2.02(\mathrm{dd}, J=24.3,11.4 \mathrm{~Hz}, 6 \mathrm{H}), 1.92(\mathrm{~d}, J=8.3 \mathrm{~Hz}, 4 \mathrm{H}), 1.81(\mathrm{dd}, J=18.6,9.6$ $\mathrm{Hz}, 4 \mathrm{H}), 1.77(\mathrm{~d}, J=10.0 \mathrm{~Hz}, 3 \mathrm{H}), 1.69(\mathrm{~d}, J=10.0 \mathrm{~Hz}, 2 \mathrm{H}), 1.27(\mathrm{~s}, 6 \mathrm{H}) .{ }^{13} \mathbf{C} \mathbf{~ N M R}\left(176 \mathrm{MHz}, \mathrm{CDCl}_{3}\right) \delta 178.25$, $174.55,161.14,133.08,132.54,113.16,90.50,77.62$, 76.87, 70.13, 57.05, 53.94, 53.53, 52.50, 48.50, 47.81, 41.86, 38.35, 17.48, 14.35. HRMS (ESI+): calculated for $\mathrm{C}_{20} \mathrm{H}_{24} \mathrm{O}_{7}[\mathrm{M}+\mathrm{Na}]^{+}: 399.1420$, found: 399.1418 . 


\section{JRA-030}

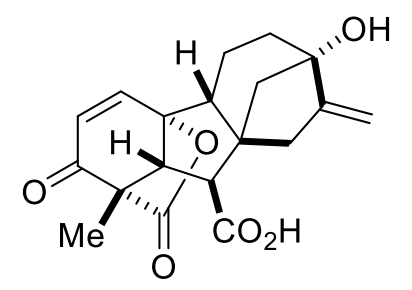

JRA-030

Gibberellic acid (JRA-001, $5 \mathrm{~g}$ ) was dissolved in DMSO (60 mL) and IBX (5.25 g, $1.3 \mathrm{eq})$ was added. The reaction was allowed to stir for $2 \mathrm{~h}$ before being quenched by the addition of water. The mixture was filtered, and the filtrate was washed with cold water and extracted with ethyl acetate. The combined extracts were washed with brine, dried over sodium sulfate and concentrated to yield JRA-030 (601 mg, 12\% yield) as a white solid after gradient chromatographic separation on silica gel (dichloromethane/methanol). ${ }^{1} \mathbf{H}$ NMR (401 MHz, CD $\left.{ }_{3} \mathrm{OD}\right) \delta 7.48(\mathrm{~d}, J=9.4 \mathrm{~Hz}, 1 \mathrm{H}), 6.02(\mathrm{~d}, J=9.5 \mathrm{~Hz}, 1 \mathrm{H}), 5.23(\mathrm{~s}, 1 \mathrm{H}), 4.95(\mathrm{~s}, 1 \mathrm{H}), 3.52(\mathrm{~d}$, $J=10.5 \mathrm{~Hz}, 1 \mathrm{H}), 2.81(\mathrm{~d}, J=10.5 \mathrm{~Hz}, 1 \mathrm{H}), 2.38(\mathrm{~d}, J=15.5 \mathrm{~Hz}, 1 \mathrm{H}), 2.26(\mathrm{~d}, J=15.3 \mathrm{~Hz}, 1 \mathrm{H}), 2.16(\mathrm{dd}$, $J=11.0,5.7 \mathrm{~Hz}, 1 \mathrm{H}), 2.09-2.01(\mathrm{~m}, 1 \mathrm{H}), 2.01-1.93(\mathrm{~m}, 2 \mathrm{H}), 1.88-1.78(\mathrm{~m}, 3 \mathrm{H}), 1.22(\mathrm{~s}, 3 \mathrm{H}) .{ }^{13} \mathrm{C}$ NMR $\left(126 \mathrm{MHz}, \mathrm{CD}_{3} \mathrm{OD}\right) \delta 193.74,175.11,174.43,158.04,149.75,129.51,107.76,91.43,78.47,66.29$, 63.46, 53.27, 52.20, 50.63, 45.57, 43.94, 39.63, 17.92, 11.87. HRMS (ESI+): calculated for $\mathrm{C}_{19} \mathrm{H}_{20} \mathrm{O}_{6}$ $[\mathrm{M}+\mathrm{Na}]^{+}:$367.1158, found: 367.1153 .

\section{JRA-031}

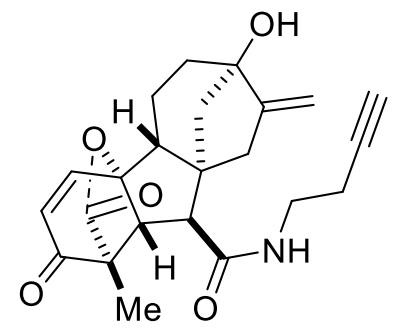

JRA-031

JRA-030 (80 mg), 1-amino-3-butyne (26.6 mg, $1.67 \mathrm{eq}), \mathrm{EDC} \cdot \mathrm{HCl}(73.8 \mathrm{mg}, 1.67 \mathrm{eq})$, and DMAP (9.4 $\mathrm{mg}, 0.33 \mathrm{eq})$ were dissolved in dichloromethane $(2 \mathrm{~mL})$ and allowed to stir at $20{ }^{\circ} \mathrm{C}$ for $14 \mathrm{~h}$. The reaction was separated between water and ethyl acetate, and the aqueous fraction was extracted with ethyl acetate. The combined organic extracts were washed with water and brine, dried over sodium sulfate, and concentrated. JRA-031 (72 mg, 78\% yield) was isolated as a white foam after gradient chromatographic separation on silica gel (dichloromethane/methanol). A sample was purified by RP-HPLC on a Phenominex C18 column prior to biological testing. ${ }^{1} \mathbf{H}$ NMR $\left(500 \mathrm{MHz}, \mathrm{CDCl}_{3}\right) \delta 7.28(\mathrm{~d}, J=9.4 \mathrm{~Hz}, 1 \mathrm{H}), 6.18(\mathrm{t}, J=$ $5.8 \mathrm{~Hz}, 1 \mathrm{H}), 6.05(\mathrm{~d}, J=9.4 \mathrm{~Hz}, 1 \mathrm{H}), 5.26(\mathrm{~s}, 1 \mathrm{H}), 4.99(\mathrm{~s}, 1 \mathrm{H}), 3.65$ (d, $J=9.8 \mathrm{~Hz}, 1 \mathrm{H}), 3.42(\mathrm{q}, J=6.2$ $\mathrm{Hz}, 2 \mathrm{H}), 2.60(\mathrm{~d}, J=9.8 \mathrm{~Hz}, 1 \mathrm{H}), 2.42(\mathrm{td}, J=6.2,2.6 \mathrm{~Hz}, 2 \mathrm{H}), 2.37-2.26(\mathrm{~m}, 2 \mathrm{H}), 2.13-2.08(\mathrm{~m}, 3 \mathrm{H})$, $2.07-2.00(\mathrm{~m}, 2 \mathrm{H}), 1.89-1.77(\mathrm{~m}, 3 \mathrm{H}), 1.69(\mathrm{~d}, J=10.5 \mathrm{~Hz}, 1 \mathrm{H}), 1.31(\mathrm{~s}, 3 \mathrm{H}) .{ }^{13} \mathrm{C} \mathrm{NMR}(126 \mathrm{MHz}$, $\left.\mathrm{CDCl}_{3}\right) \delta 191.79,173.96,170.01,156.34,147.37,129.36,107.72,90.21,81.33,78.32,70.66,65.31,62.62$, 53.64, 51.23, 50.16, 46.21, 43.15, 38.43, 38.24, 19.47, 17.28, 11.55. HRMS (ESI+): calculated for $\mathrm{C}_{23} \mathrm{H}_{25} \mathrm{O}_{5} \mathrm{~N}[\mathrm{M}+\mathrm{Na}]^{+}: 418.1630$, found: 418.1625 . 


\section{JRA-032}

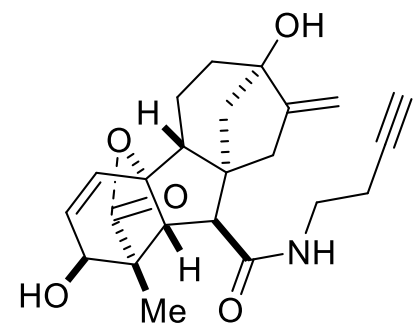

JRA-032

Gibberellic acid (JRA-001, 3, $115 \mathrm{mg}$ ), 1-amino-3-butyne (38.2 mg, $1.67 \mathrm{eq})$, EDC· $\mathrm{HCl}$ (106 mg, $1.67 \mathrm{eq}$ ), and DMAP (13.5 mg, $0.33 \mathrm{eq})$ were dissolved in dichloromethane $(2 \mathrm{~mL})$ and allowed to stir at $20^{\circ} \mathrm{C}$ for $8 \mathrm{~h}$. The reaction was separated between water and ethyl acetate, and the aqueous fraction was extracted with ethyl acetate. The combined organic extracts were washed with water and brine, dried over sodium sulfate, and concentrated. JRA-031 (35 mg, 27\% yield) was isolated as a white foam after gradient chromatographic separation on silica gel (dichloromethane/methanol). A sample was purified by RP-HPLC on a Phenominex C18 column prior to biological testing. ${ }^{1} \mathbf{H}$ NMR $\left(401 \mathrm{MHz}, \mathrm{CD}_{3} \mathrm{OD}\right) \delta 6.37(\mathrm{~d}, J=9.3$ $\mathrm{Hz}, 1 \mathrm{H}), 5.86(\mathrm{dd}, J=9.3,3.6 \mathrm{~Hz}, 1 \mathrm{H}), 5.17(\mathrm{~s}, 1 \mathrm{H}), 4.91(\mathrm{~s}, 1 \mathrm{H}), 3.97(\mathrm{~d}, J=3.5 \mathrm{~Hz}, 1 \mathrm{H}), 3.40-3.33(\mathrm{~m}$, $1 \mathrm{H}), 3.30(\mathrm{dt}, J=8.9,4.3 \mathrm{~Hz}, 4 \mathrm{H}), 3.25(\mathrm{~d}, J=10.1 \mathrm{~Hz}, 1 \mathrm{H}), 2.63(\mathrm{~d}, J=10.2 \mathrm{~Hz}, 1 \mathrm{H}), 2.39$ (ddd, $J=9.7$, $6.5,2.9 \mathrm{~Hz}, 2 \mathrm{H}), 2.28(\mathrm{dt}, J=20.9,11.1 \mathrm{~Hz}, 3 \mathrm{H}), 2.03-1.85(\mathrm{~m}, 4 \mathrm{H}), 1.79-1.69(\mathrm{~m}, 3 \mathrm{H}), 1.21(\mathrm{~s}, 3 \mathrm{H})$. ${ }^{13}$ C NMR $\left(176 \mathrm{MHz}, \mathrm{CD}_{3} \mathrm{OD}\right) \delta 181.36,173.80,158.31,134.10,133.24,107.16,92.80,82.32,78.80$, 71.11, 70.70, 55.06, 54.28, 53.44, 52.13, 51.72, 45.99, 44.53, 39.85, 39.61, 19.74, 18.06, 14.95. HRMS (ESI+): calculated for $\mathrm{C}_{23} \mathrm{H}_{27} \mathrm{O}_{5} \mathrm{~N}[\mathrm{M}+\mathrm{Na}]^{+}$: 420.1786 , found: 420.1776 . 


\section{Supplementary Information Section 4: NMR Spectra}

${ }^{1} \mathrm{HNMR}$ (401 MHz, CDCl 3 ), ${ }^{13} \mathrm{CNMR}\left(176 \mathrm{MHz}, \mathrm{CD}_{3} \mathrm{OD}\right)$, JRA-013.
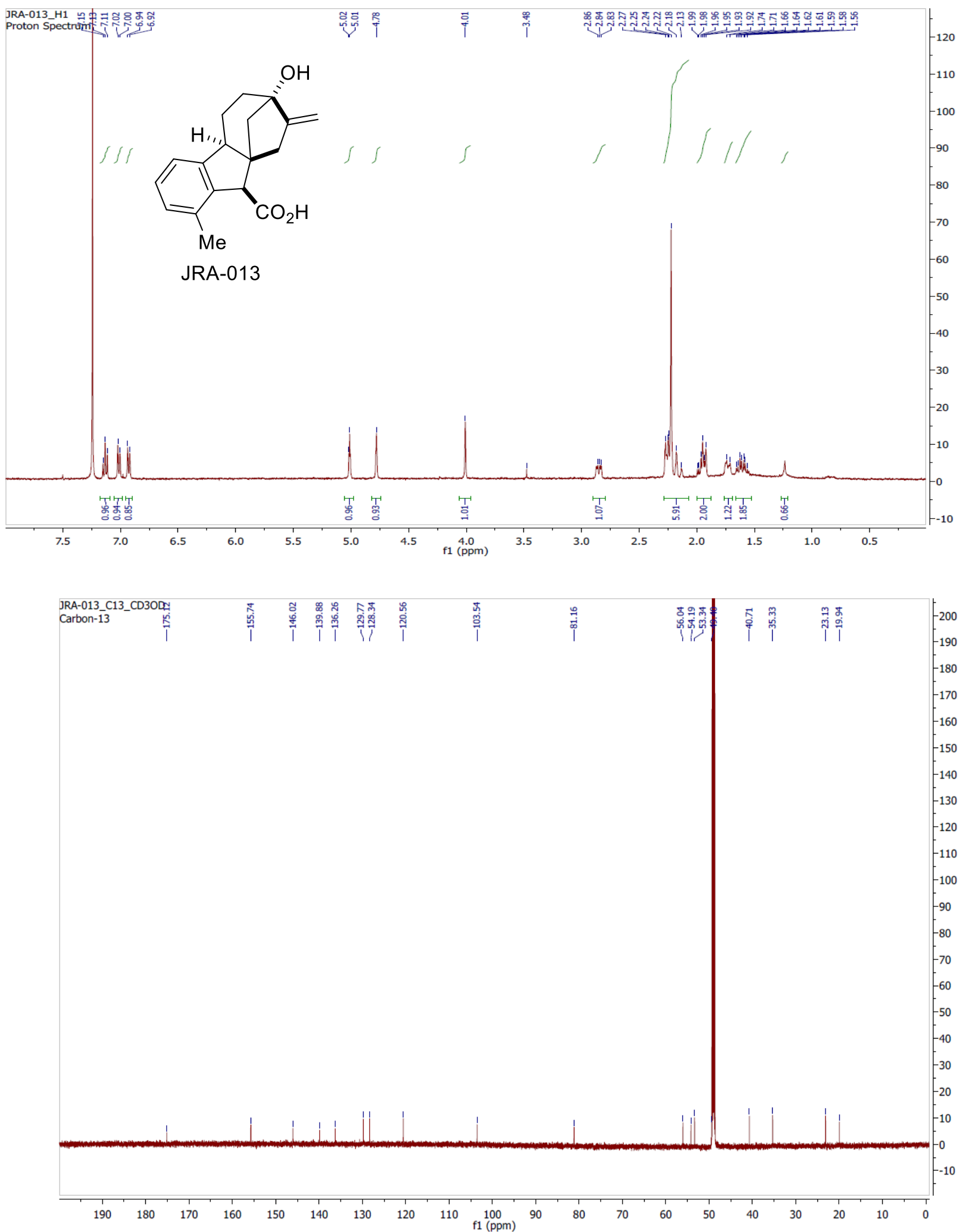
${ }^{1} \mathrm{HNMR}\left(700 \mathrm{MHz}, \mathrm{CDCl}_{3}\right),{ }^{13} \mathrm{CNMR}\left(176 \mathrm{MHz}, \mathrm{CDCl}_{3}\right)$, JRA-014.
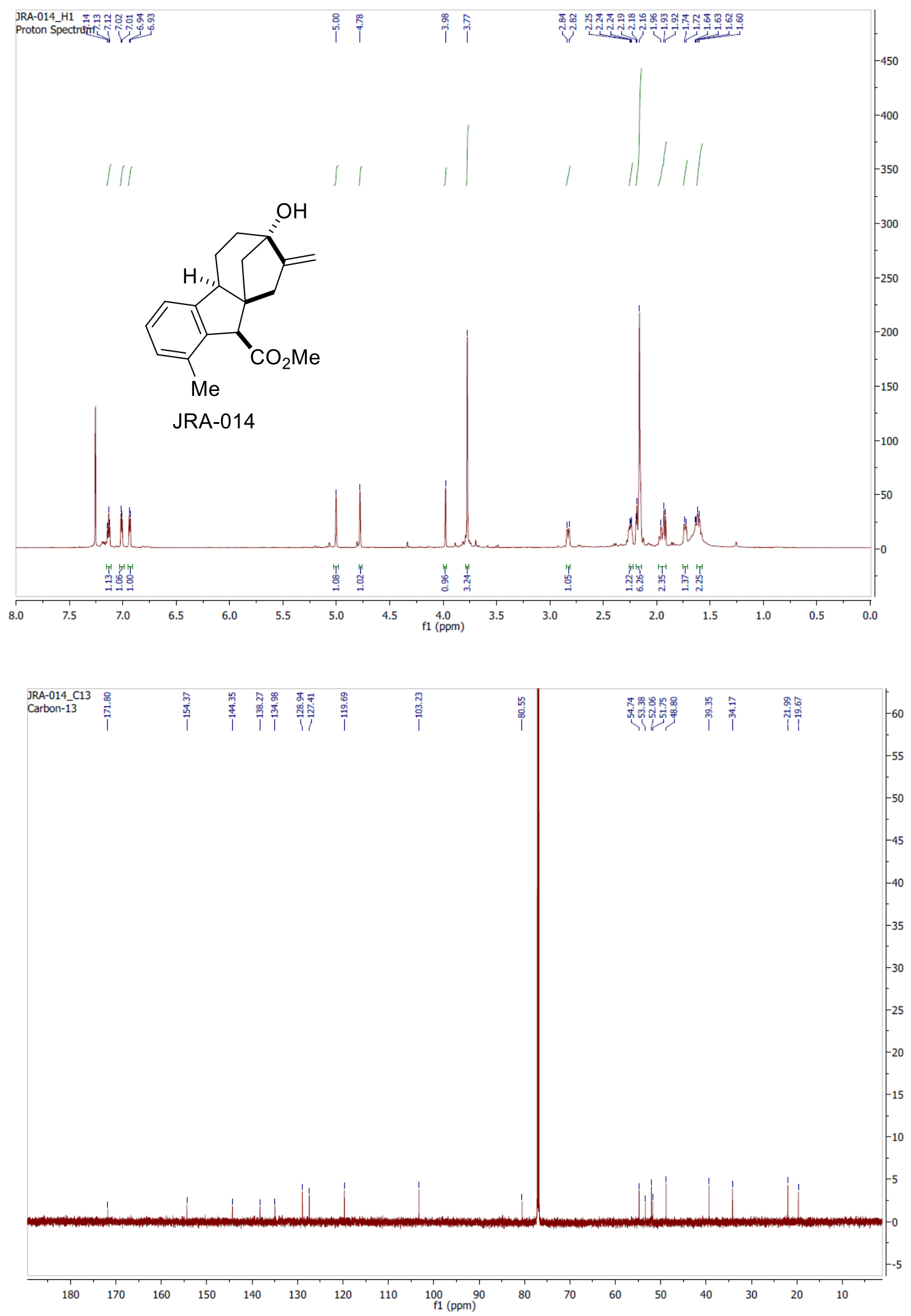
${ }^{1} \mathrm{HNMR}\left(700 \mathrm{MHz}, \mathrm{CDCl}_{3}\right),{ }^{13} \mathrm{CNMR}\left(176 \mathrm{MHz}, \mathrm{CDCl}_{3}\right)$, JRA-015.
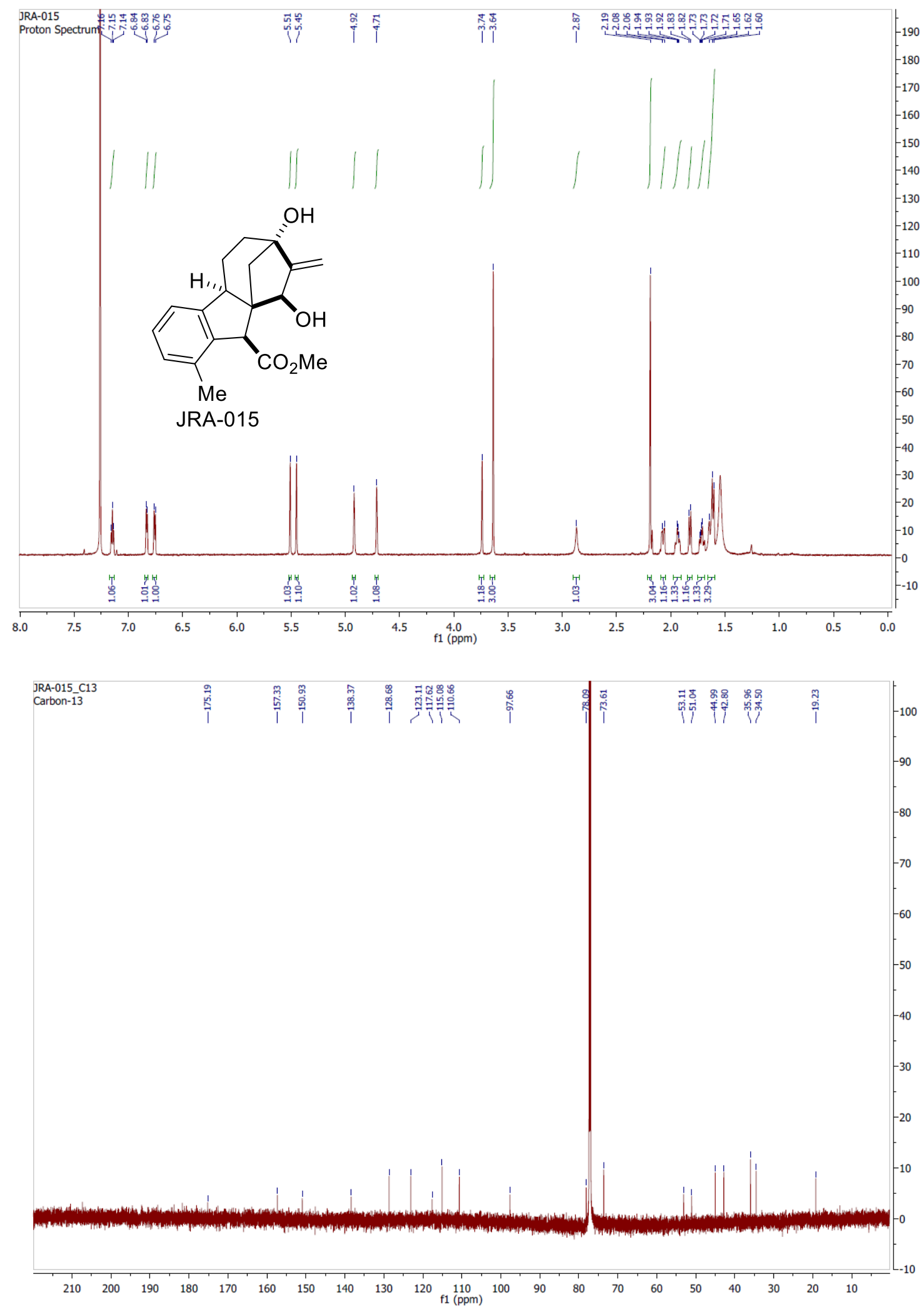
${ }^{1} \mathrm{HNMR}\left(401 \mathrm{MHz}, \mathrm{CDCl}_{3}\right),{ }^{13} \mathrm{CNMR}\left(176 \mathrm{MHz}, \mathrm{CDCl}_{3}\right)$, JRA-017.
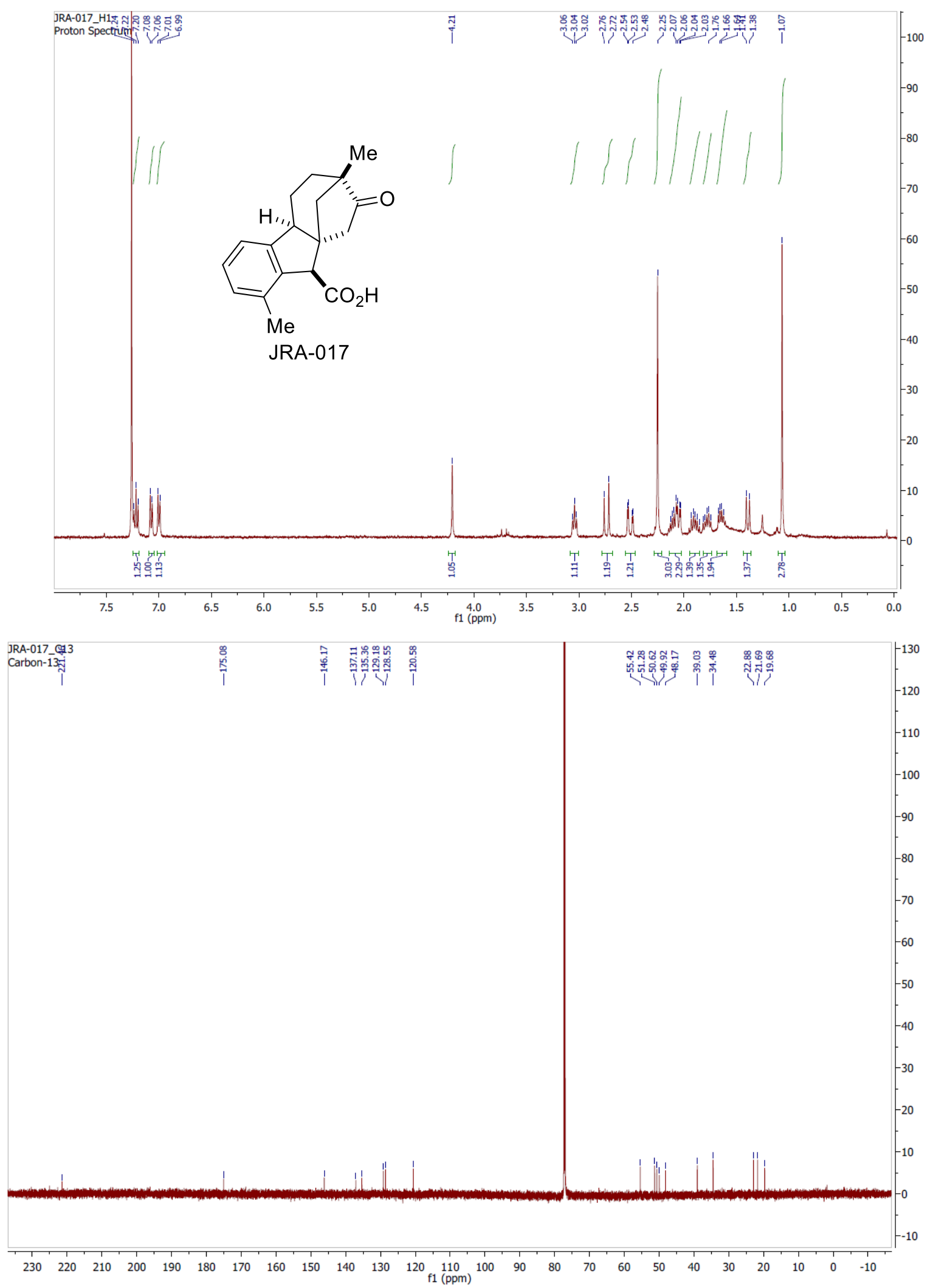
${ }^{1} \mathrm{HNMR}\left(401 \mathrm{MHz}, \mathrm{CDCl}_{3}\right),{ }^{13} \mathrm{CNMR}\left(176 \mathrm{MHz}, \mathrm{CDCl}_{3}\right)$, JRA-018.
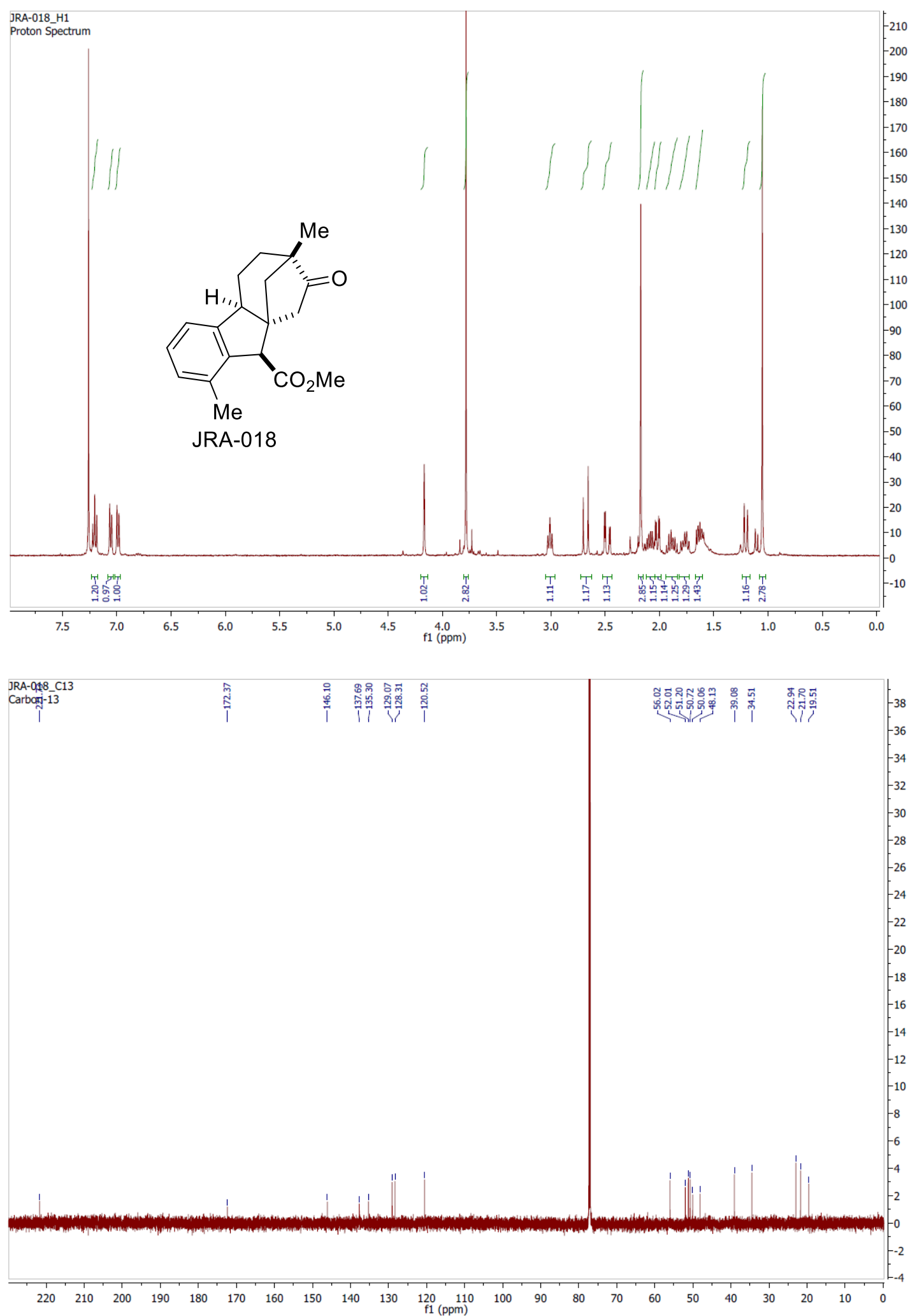
${ }^{1} \mathrm{HNMR}\left(401 \mathrm{MHz}, \mathrm{CDCl}_{3}\right),{ }^{13} \mathrm{CNMR}\left(176 \mathrm{MHz}, \mathrm{CDCl}_{3}\right)$, JRA-019.

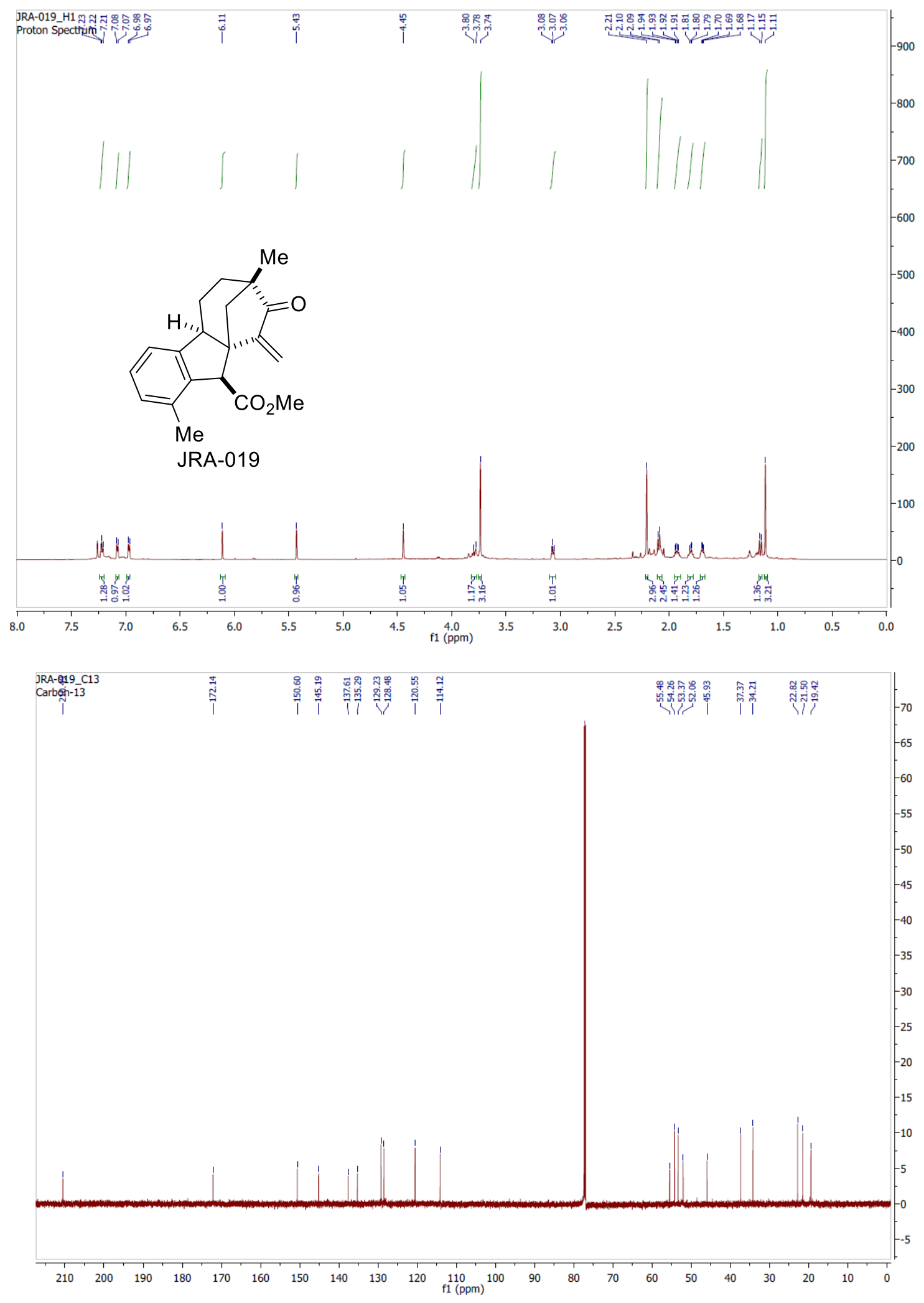


${ }^{1} \mathrm{HNMR}\left(401 \mathrm{MHz}, \mathrm{CDCl}_{3}\right),{ }^{13} \mathrm{CNMR}\left(176 \mathrm{MHz}, \mathrm{CDCl}_{3}\right)$, JRA-021.
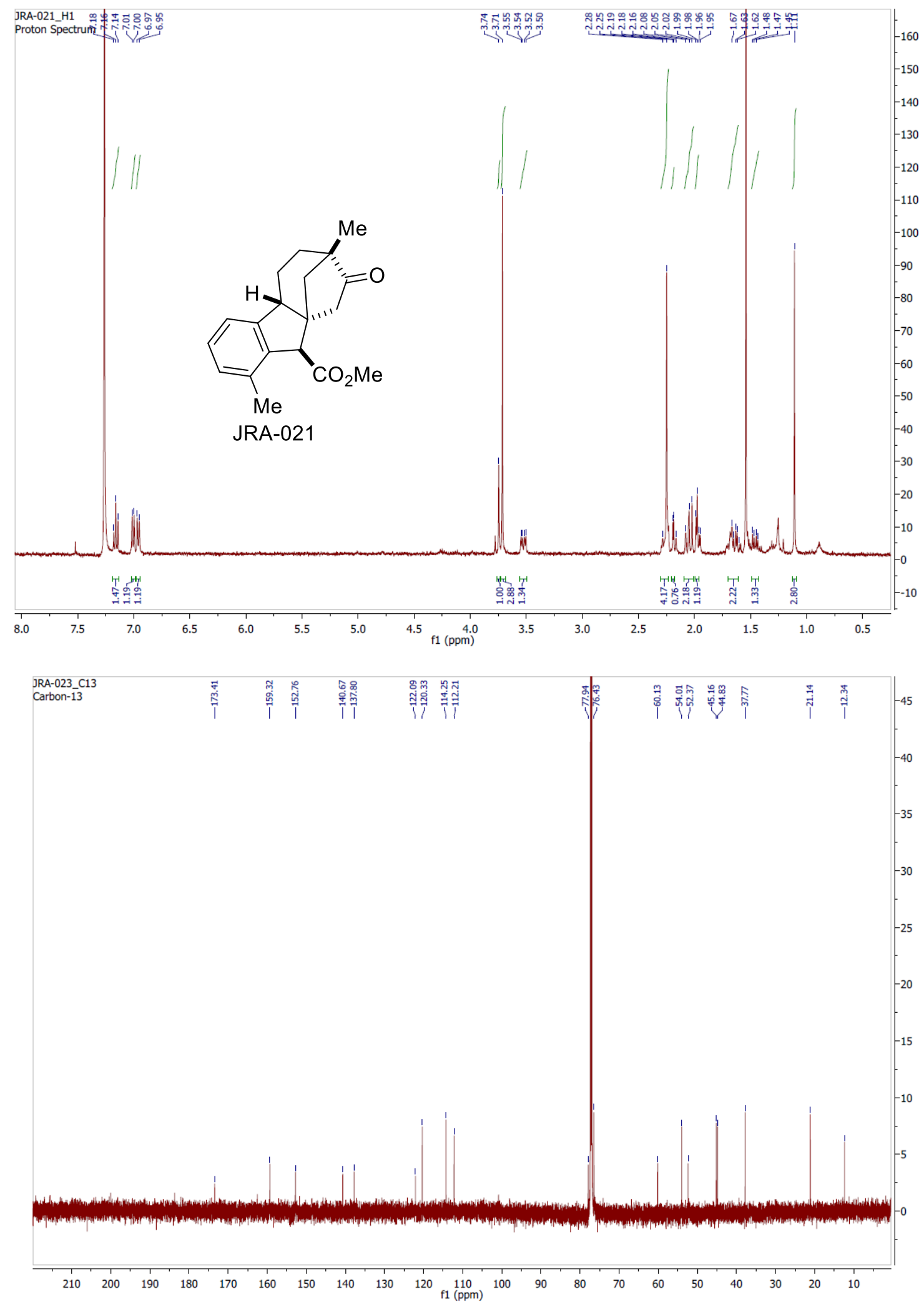
${ }^{1} \mathrm{HNMR}\left(700 \mathrm{MHz}, \mathrm{CDCl}_{3}\right),{ }^{13} \mathrm{CNMR}\left(176 \mathrm{MHz}, \mathrm{CDCl}_{3}\right)$, JRA-022.

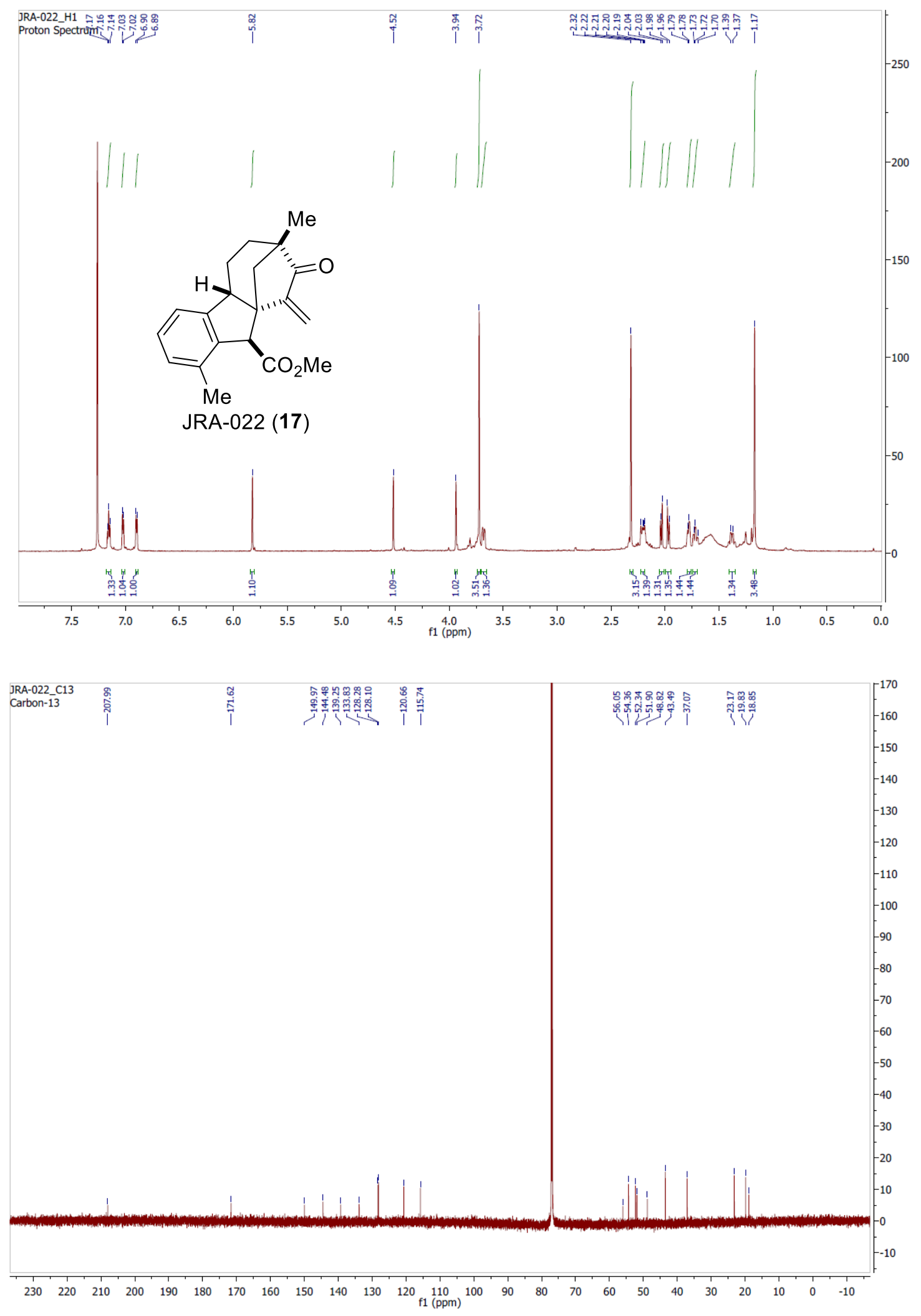


${ }^{1} \mathrm{HNMR}\left(401 \mathrm{MHz}, \mathrm{CDCl}_{3}\right),{ }^{13} \mathrm{CNMR}\left(176 \mathrm{MHz}, \mathrm{CDCl}_{3}\right)$, JRA-023.
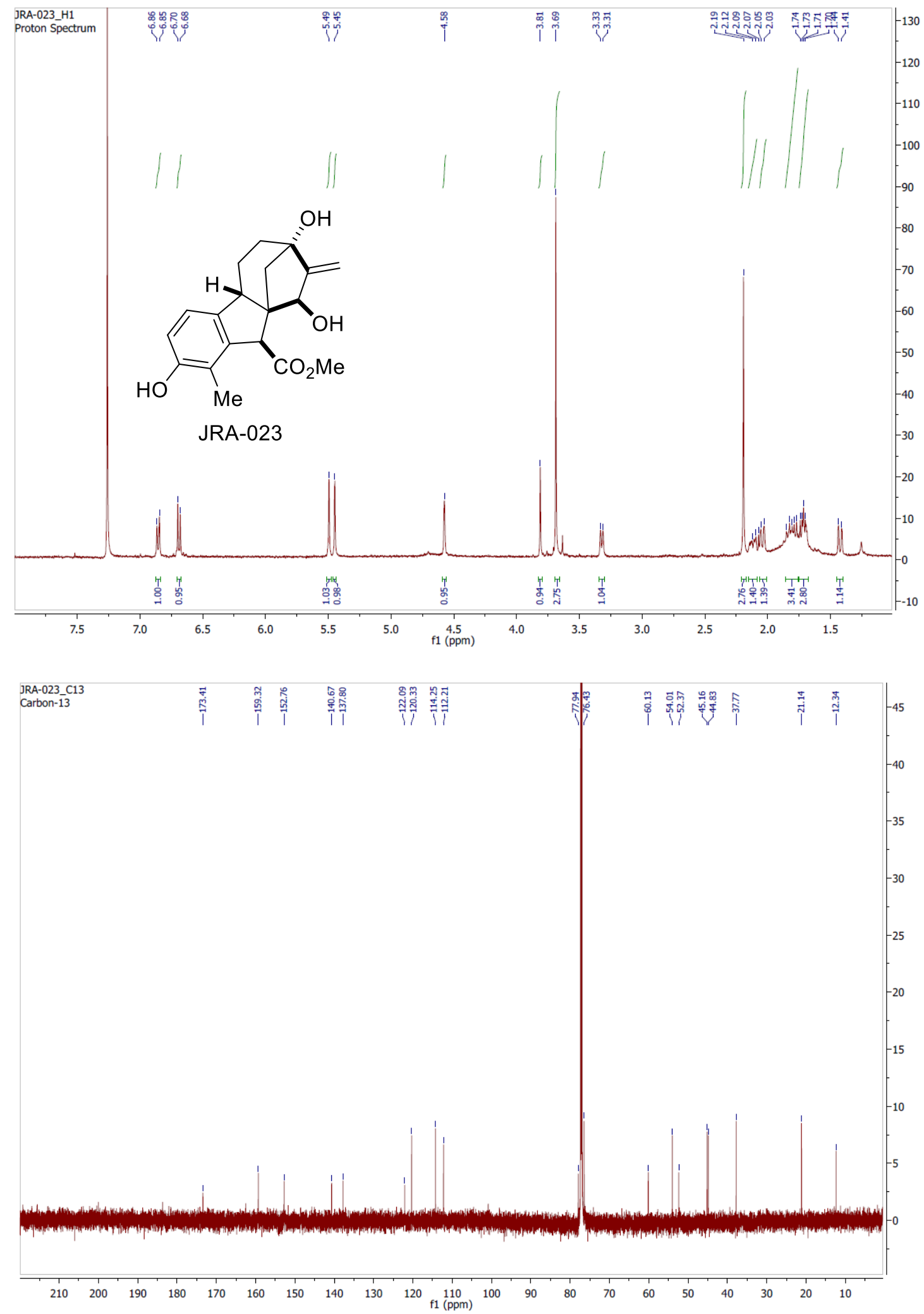
${ }^{1} \mathrm{HNMR}\left(401 \mathrm{MHz}, \mathrm{CDCl}_{3}\right),{ }^{13} \mathrm{CNMR}\left(176 \mathrm{MHz}, \mathrm{CDCl}_{3}\right)$, JRA-026.
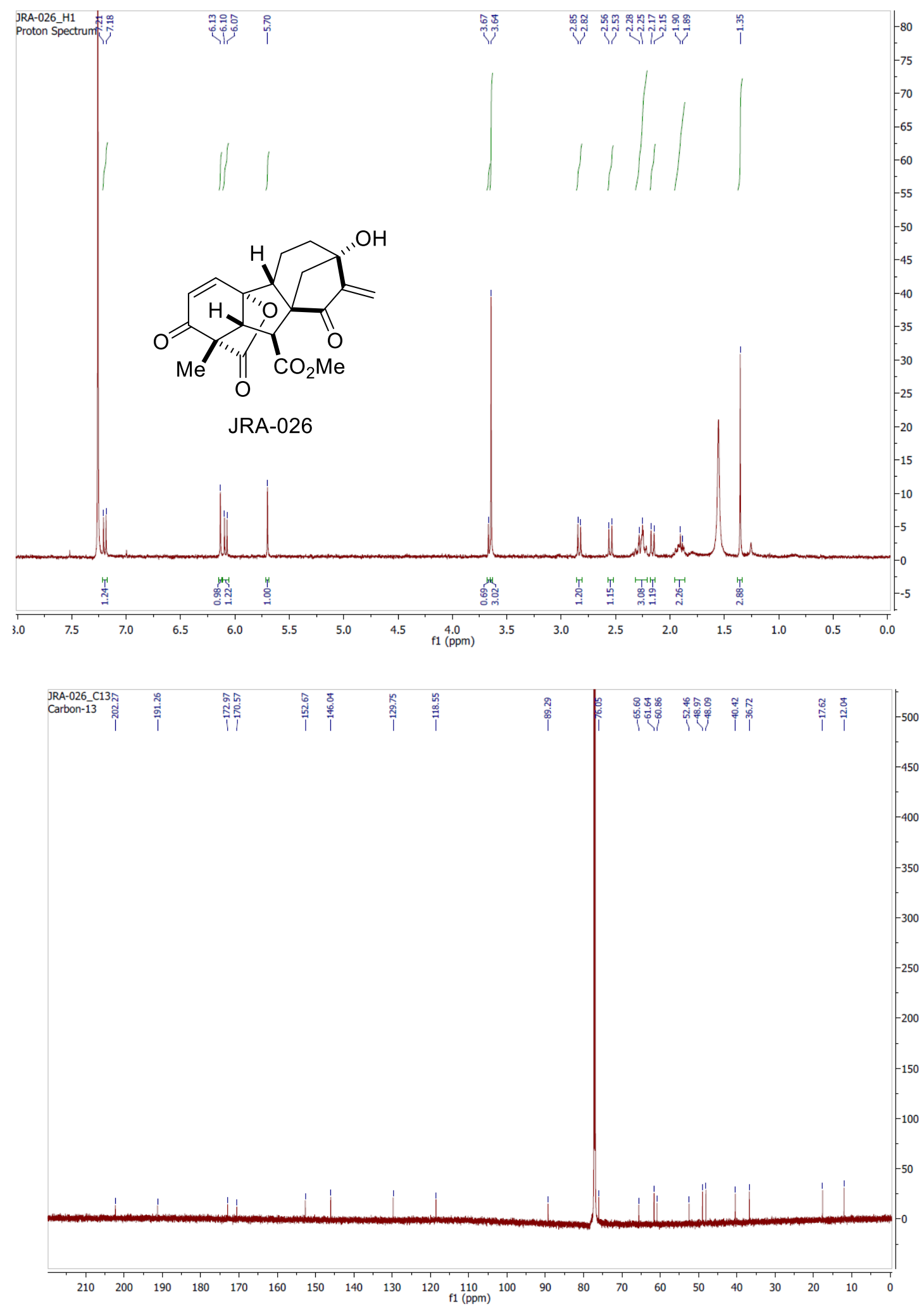
${ }^{1} \mathrm{HNMR}\left(700 \mathrm{MHz}, \mathrm{CDCl}_{3}\right),{ }^{13} \mathrm{CNMR}\left(176 \mathrm{MHz}, \mathrm{CDCl}_{3}\right)$, JRA-027.
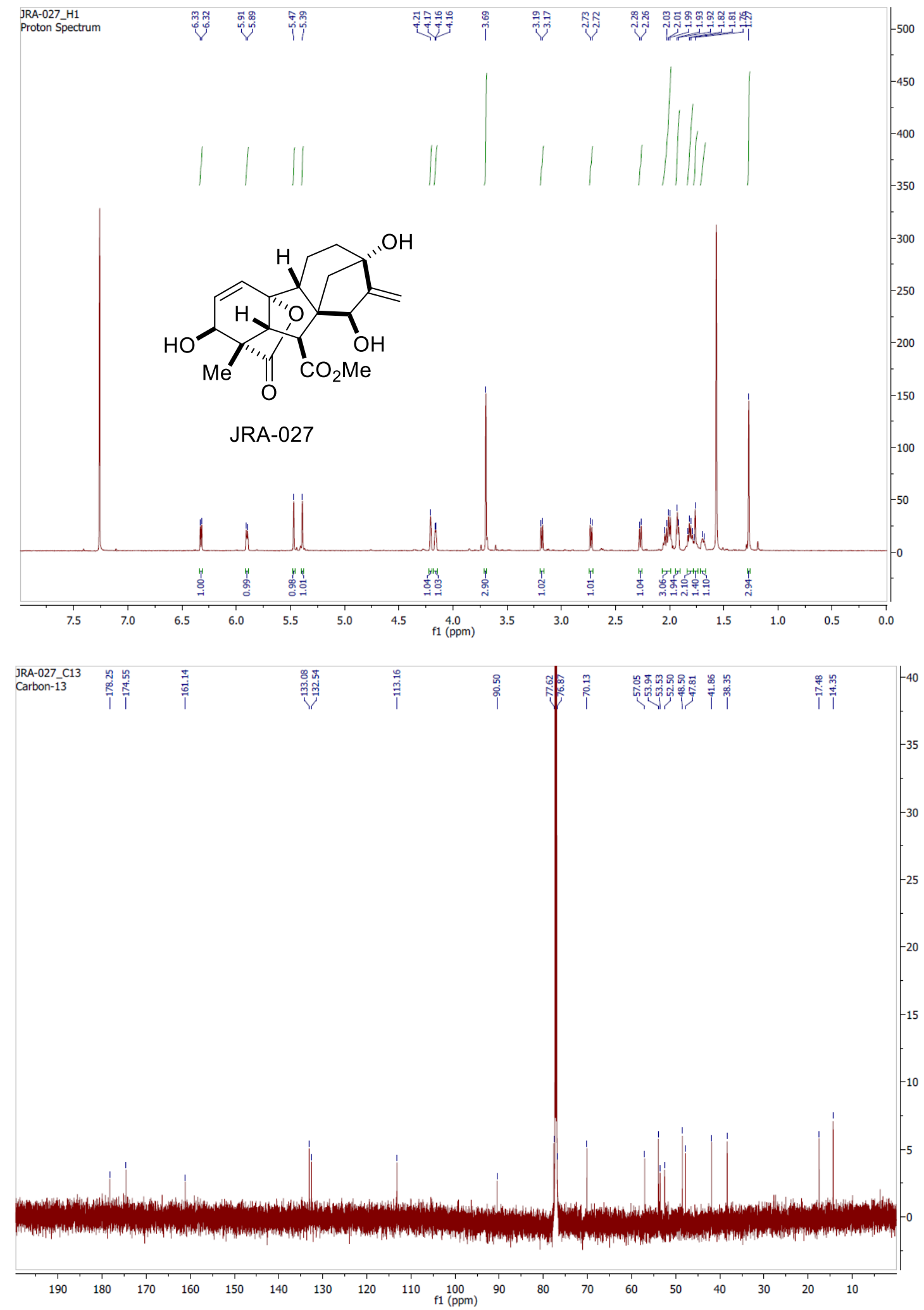
${ }^{1} \mathrm{HNMR}\left(700 \mathrm{MHz}, \mathrm{CDCl}_{3}\right),{ }^{13} \mathrm{CNMR}\left(176 \mathrm{MHz}, \mathrm{CDCl}_{3}\right)$, JRA-028.
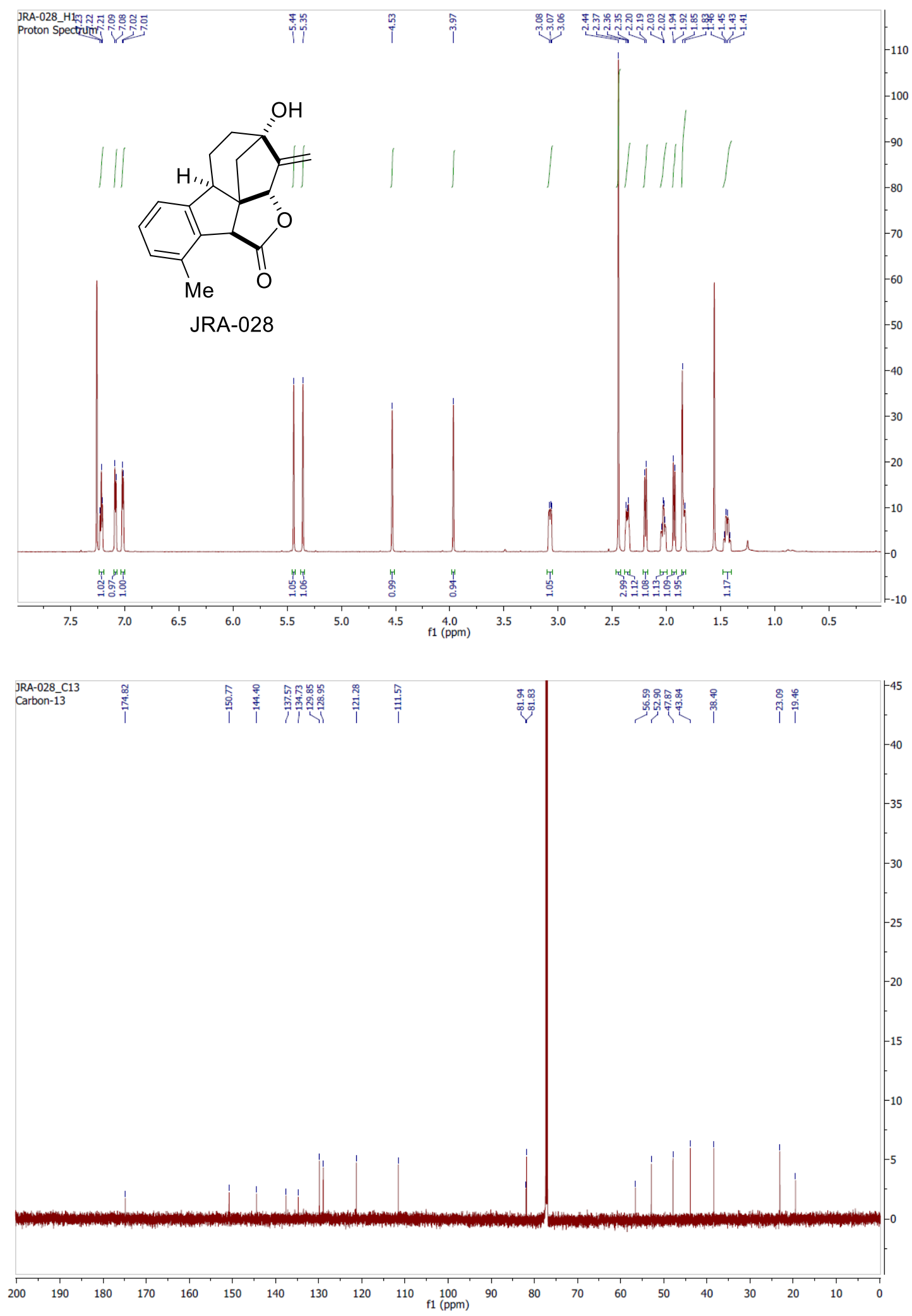
${ }^{1} \mathrm{HNMR}\left(700 \mathrm{MHz}, \mathrm{CDCl}_{3}\right),{ }^{13} \mathrm{CNMR}\left(176 \mathrm{MHz}, \mathrm{CDCl}_{3}\right.$ ), JRA-029.

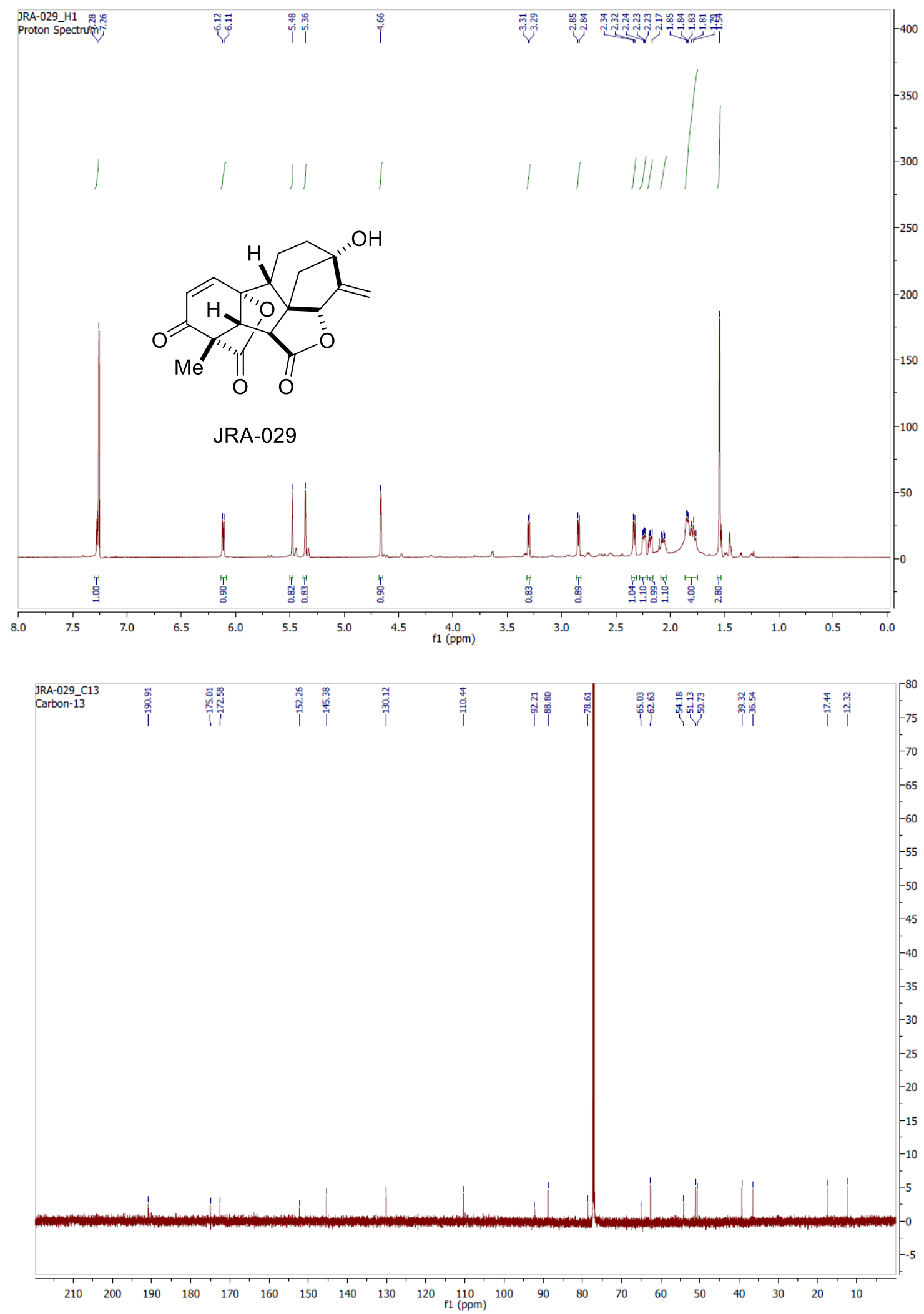


${ }^{1} \mathrm{HNMR}\left(401 \mathrm{MHz}, \mathrm{CD}_{3} \mathrm{OD}\right),{ }^{13} \mathrm{CNMR}\left(126 \mathrm{MHz}, \mathrm{CD}_{3} \mathrm{OD}\right)$, JRA-030.
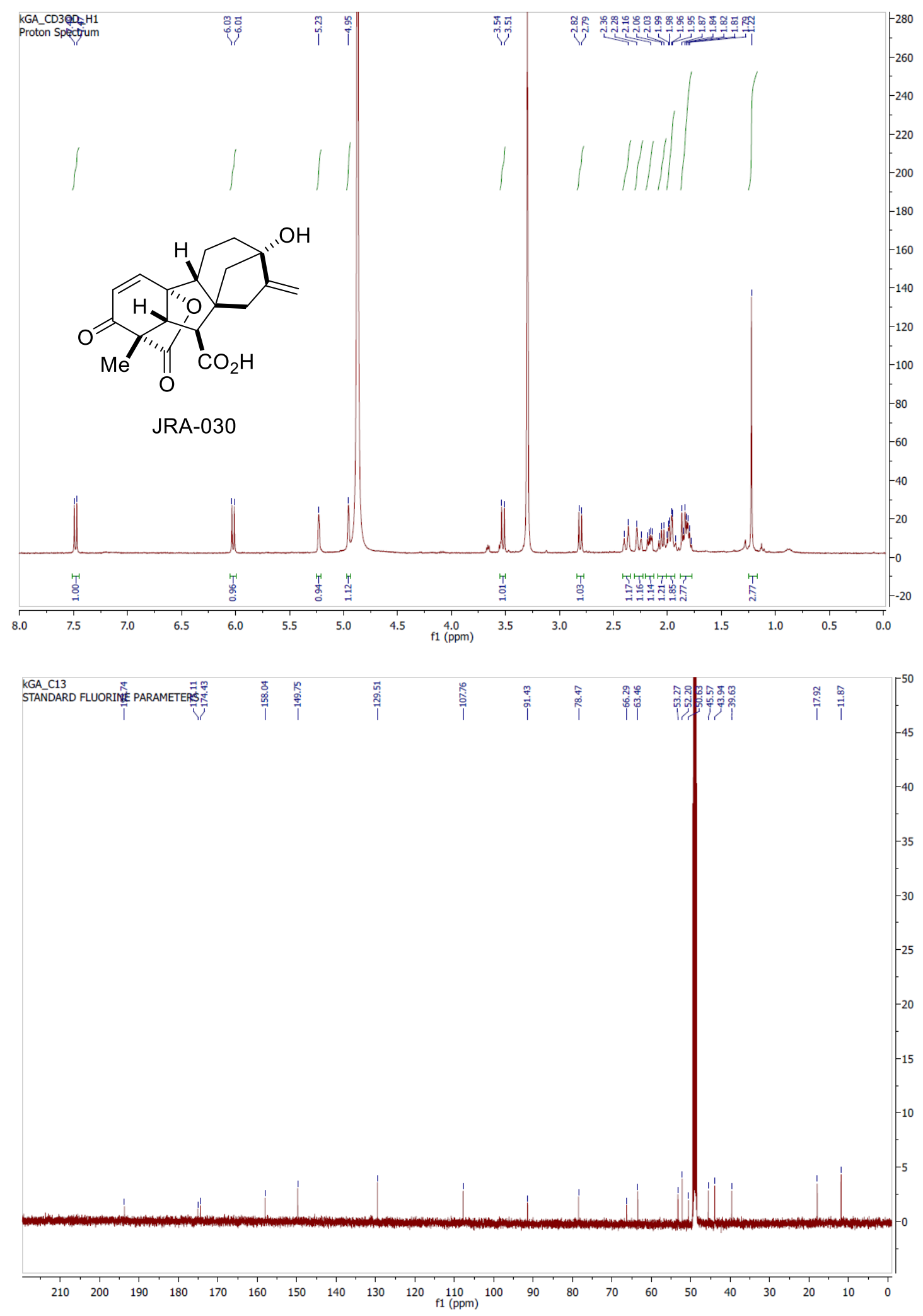
${ }^{1} \mathrm{HNMR}\left(500 \mathrm{MHz}, \mathrm{CDCl}_{3}\right),{ }^{13} \mathrm{CNMR}\left(126 \mathrm{MHz}, \mathrm{CDCl}_{3}\right)$, JRA-031.
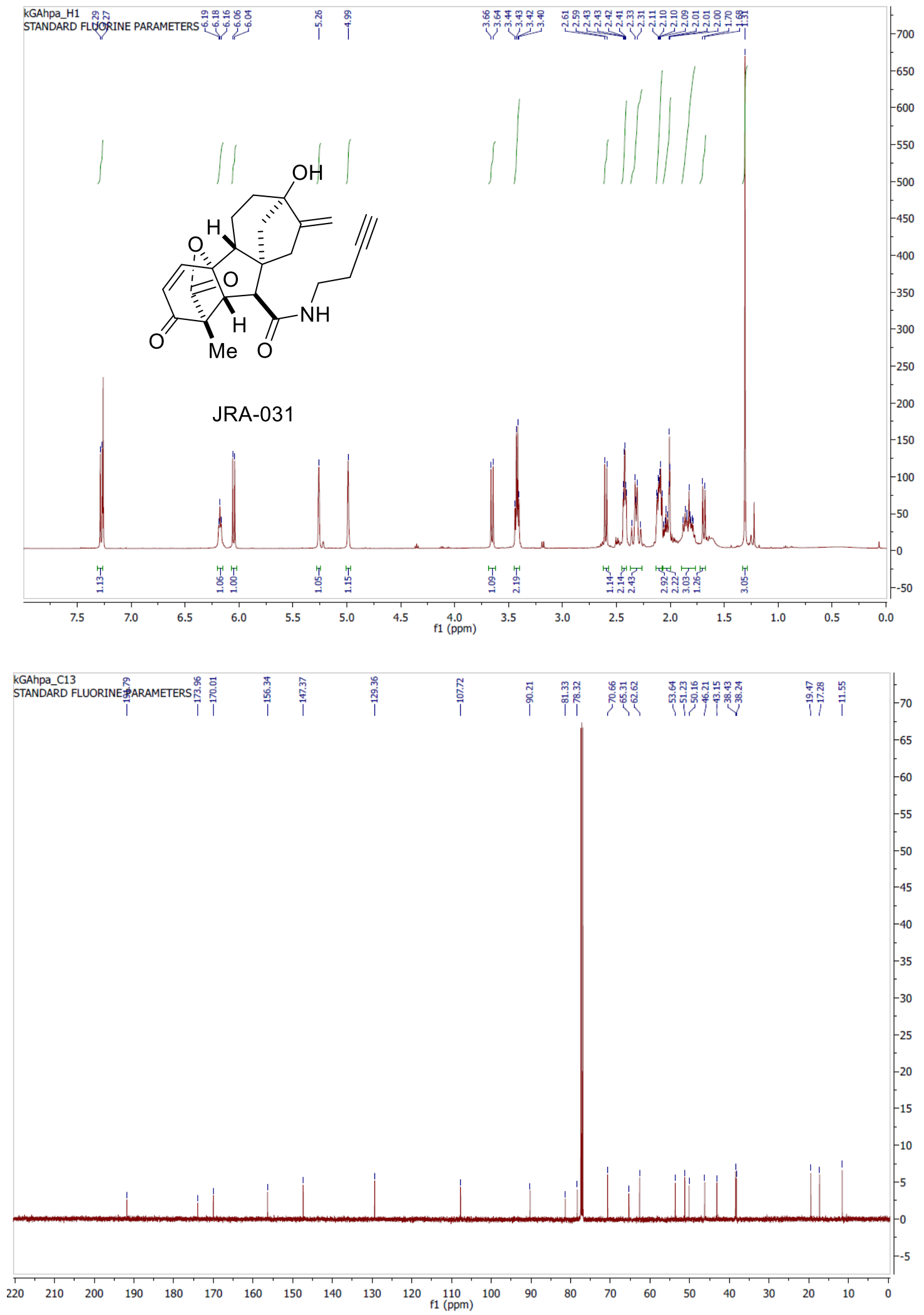
${ }^{1} \mathrm{HNMR}\left(401 \mathrm{MHz}, \mathrm{CD}_{3} \mathrm{OD}\right),{ }^{13} \mathrm{CNMR}\left(176 \mathrm{MHz}, \mathrm{CD}_{3} \mathrm{OD}\right)$, JRA-032.
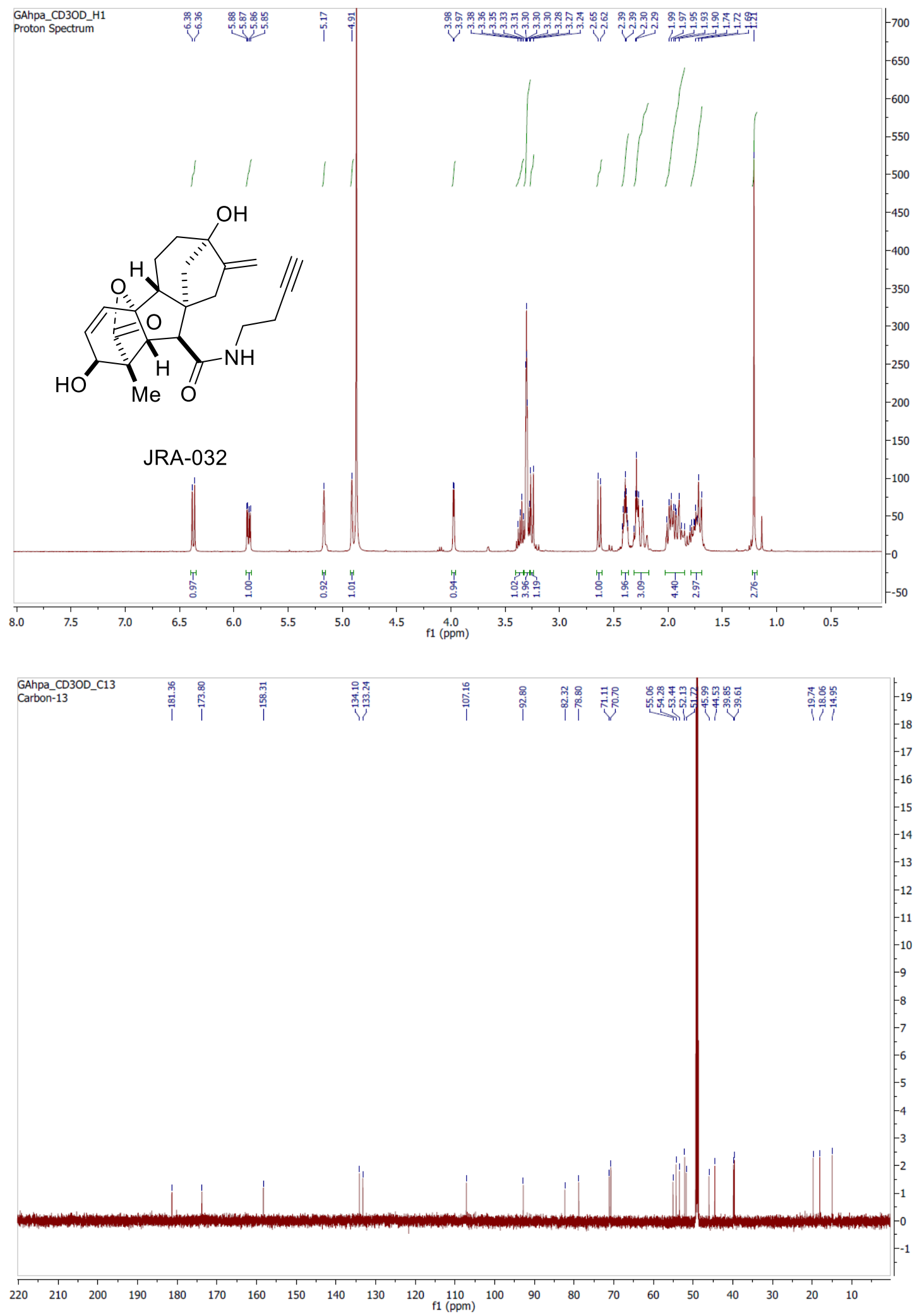


\section{Supplemental Information Section 5: References}

(1) Weerapana, E., Wang, C., Simon, G. M., Richter, F., Khare, S., Dillon, M. B. D., Cravatt, B. F. Quantitative reactivity profiling predicts functional cysteines in proteomes. Nature, 2010, 468 (7325), 790-797.

(2) Eng, J.K., McCormack, A.L. and Yates, J.R. An approach to correlate tandem mass spectral data of peptides with amino acid sequences in a protein database. J. Am. Soc. Mass Spec. 1994, 5 (11), 976-989.

(3) Tabb, D.L., McDonald, W.H. and Yates, J.R. DTASelect and Contrast: tools for assembling and comparing protein identifications from shotgun proteomics. J. Proteom. Res. 2002, 1 (1), 21-26.

(4) Annand, J. R.; Bruno, P. A.; Mapp, A. K.; Schindler, C. S. Synthesis and Biological Evaluation of Pharbinilic Acid and Derivatives as NF-KB Pathway Inhibitors. Chem. Commun. 2015, 51 (43), 8990-8993. 